
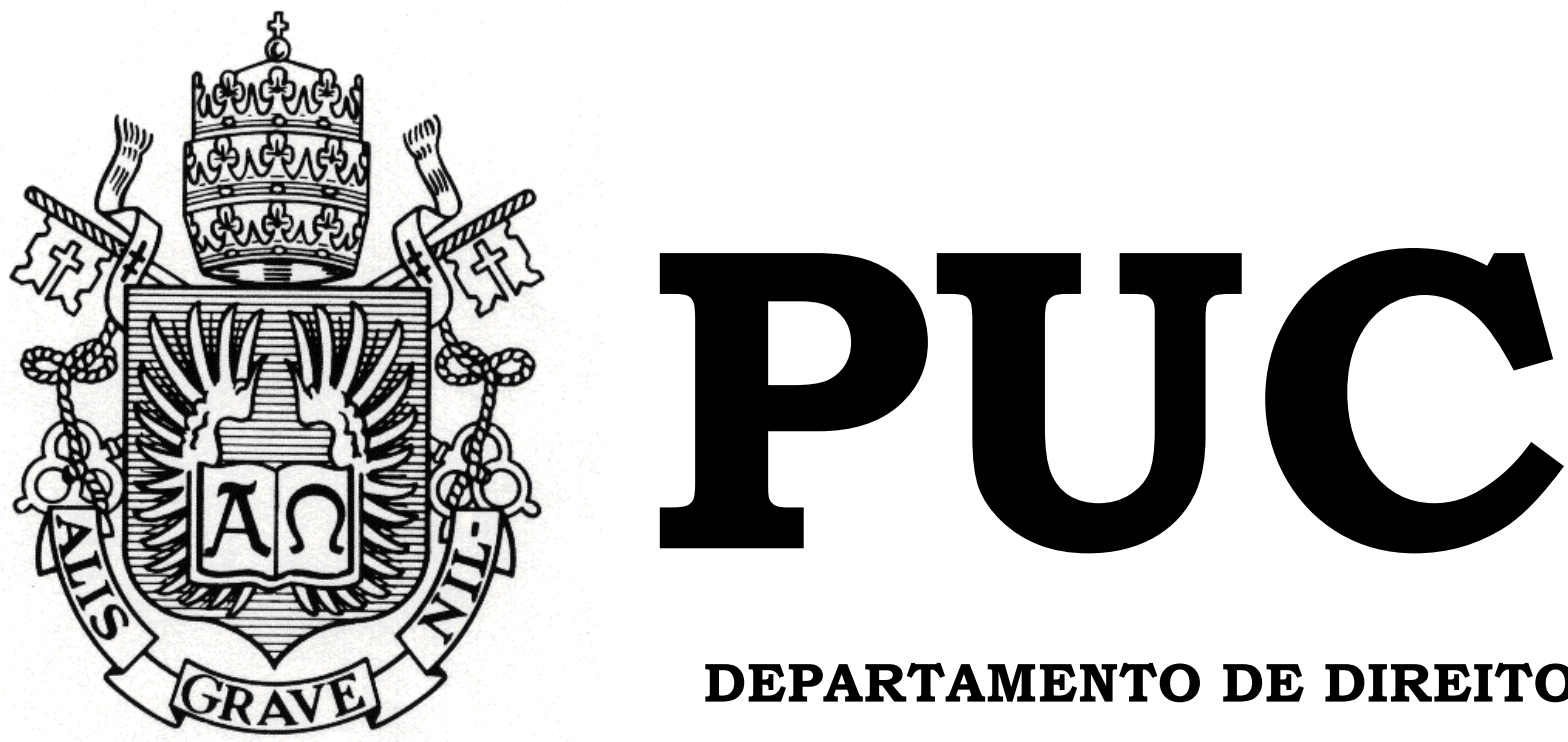

DEPARTAMENTO DE DIREITO

\title{
Reequilíbrio Econômico-Financeiro nos Contratos EPC
}

\author{
por \\ Clara Drumond Degrazia Ribeiro \\ ORIENTADOR: Francisco Antunes \\ Maciel Müssnich \\ 2018.2
}

PONTIFÍCIA UNIVERSIDADE CATÓLICA DO RIO DE JANEIRO

RUA MARQUÊS DE SÃO VICENTE, 225 - CEP 22453-900

RIO DE JANEIRO - BRASIL 


\section{Reequilíbrio Econômico- Financeiro nos Contratos EPC}

por

CLARA DRUMOND DEGRAZIA RIBEIRO

Monografia apresentada ao Departamento de Direito da Pontifícia Universidade Católica do Rio de Janeiro (PUC-Rio) para a obtenção do Título de Bacharel em Direito.

Orientador: $\quad$ Francisco Antunes Maciel

Müssnich. 


\section{Agradecimentos}

Aos meus pais, Fátima e Claudio, agradeço pelo amor, companheirismo, paciência infinita e apoio incondicionais ao longo de todas as fases da minha vida, especialmente por toda a compreensão no último ano.

À minha mãe agradeço por ser a grande responsável pela minha paixão pelas artes e, principalmente, por ser essa mulher forte, mas ao mesmo tempo tão amorosa e sensível, que me inspira desde criança. Ao meu pai, por todo o amor e zelo pelo qual sempre cuidou da nossa família, e por ser o maior modelo profissional que eu poderia ter. Ao meu irmão e melhor amigo, Bruno, pelos momentos de descontração e de amizade e por todos os conselhos dados. Vocês são meus maiores exemplos de como correr atrás dos sonhos e representam tudo de mais especial que existe na minha vida.

Ao Pedro, pelo companheirismo de sempre, pela amizade, convívio, suporte, amor e apoio completo nessa jornada inigualável.

A toda a minha família, por todo o zelo, preocupação, suporte e amor que me deram ao longo de toda a minha vida.

Às minhas amigas de infância, que levo comigo desde os meus três anos, deixo aqui um agradecimento especial à Re, Mano, Ju, Carolzinha e Vicky. Vocês são as irmãs que eu escolhi. Não há palavras para explicar o tanto que vocês são importantes na minha vida.

Às amigas que conheci nesses anos de PUC-Rio, pilotis, jogos jurídicos, choppadas, churrascos e estágios, obrigada pelos cadernos, ensinamentos e trocas diárias, mas também por todas as risadas e momentos que vou levar comigo para sempre. Especialmente às que me acompanharam desde o início ao fim dessa trajetória universitária: Najinha, Cami, Julib, Dia, Dib, Vek, Mafe, Nana, Carol, Lu, Carlinha, Leca, Dea, Rafa e Brenda. Obrigada pelo companheirismo, por me mostrarem que amizade não se faz só 
nas afinidades, mas também na compreensão pelas diferenças. Vocês fizeram parte da melhor fase da minha vida.

Às minhas primas e irmãs de coração, Sofia e Anais, obrigada pelos ouvidos pacientes, por estarem ao meu lado nos melhores e piores momentos, pela amizade, pela compreensão e suporte incondicionais. Eu amo muito vocês.

Aos professores da Pontifícia Universidade Católica do Rio de Janeiro, por contribuírem, cada um em sua medida, em minha formação acadêmica e profissional.

Muito obrigada a todos. 


\section{Resumo}

A presente monografa visa analisar o Contrato EPC (Engineering, Procurement and Construction) que concentra a integralidade das atividades necessárias para a implantação de empreendimento, desde a concepção até a sua operação, na mão de um único contratado. O estudo representa a evolução do contrato que se adaptou ao longo do tempo para suportar as grandes obras de infraestrutura. Com a identificação dos elementos que distinguem o EPC do tipo legal empreitada, previsto em nossa legislação, vemos que o EPC é um contrato empresarial que demanda conhecimento técnico das partes para a sua negociação, elaboração e execução. Relacionando ao EPC o instituto da onerosidade excessiva e como uma alocação eficiente dos riscos contratuais pode mitigar a sua incidência.

\section{Palavras-Chave}

Contrato EPC. EPC. Empreitada. Teoria da Imprevisão. Onerosidade Excessiva. Riscos. Força Maior. Código Civil. Alocação Contratual de Riscos. Preço. Contratante. Contratada. Dono da Obra. Epcista. 


\section{Sumário}

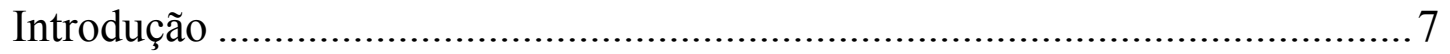

Capítulo 1: Contextualização Histórica e Social.................................................. 11

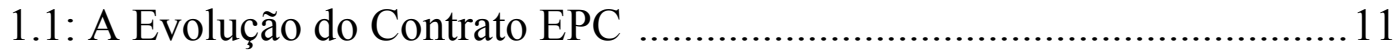

1.1.1: Do Método Convencional ao Design-Build ................................ 12

1.1.2: Do Design-Build ao Turnkey...................................................... 15

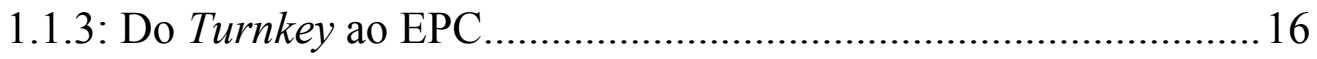

Capítulo 2: O Contrato EPC no Direito Brasileiro .......................................... 19

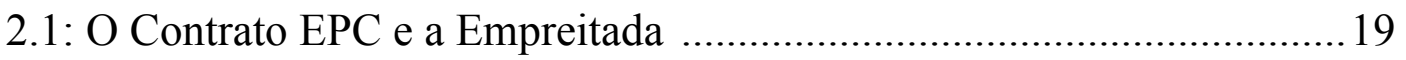

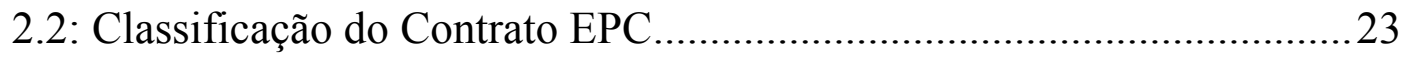

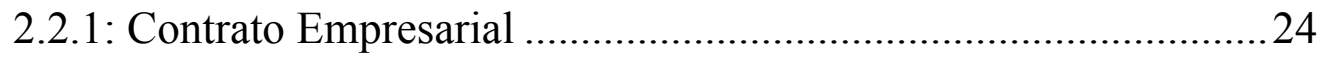

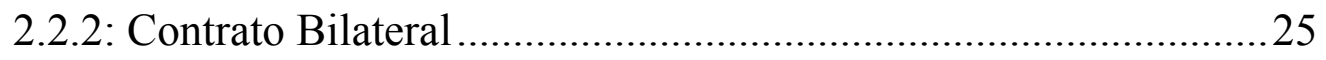

2.2.3: Contrato Consensual e Não Solene..............................................25

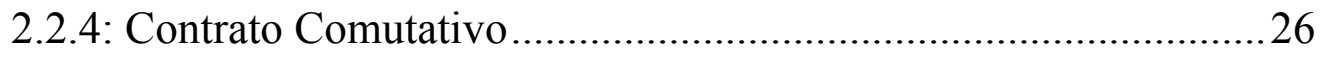

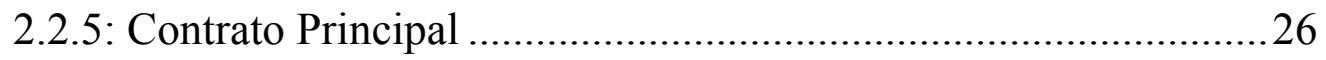

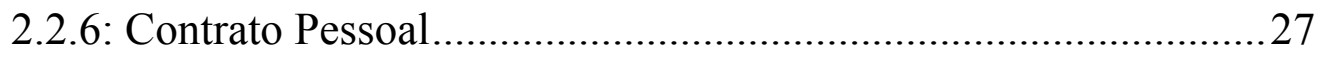

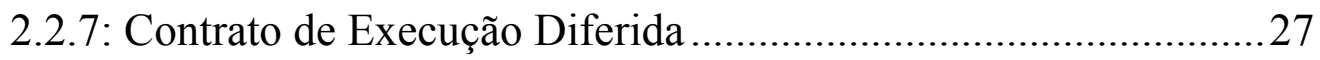

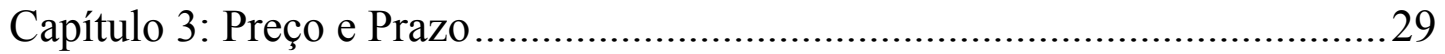

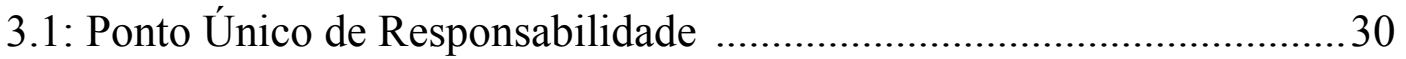

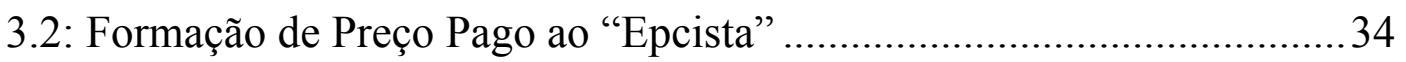

Capítulo 4: Onerosidade Excessiva..................................................................4 40

4.1: A Relativização da Força Obrigatória do Contrato ..................................40

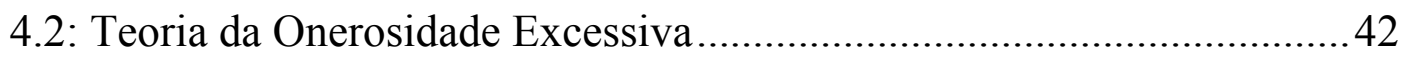

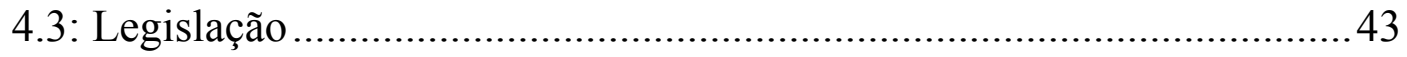

4.4: Jurisprudência dos Tribunais Brasileiros ............................................49

Capítulo 5: Alocação Contratual de Riscos .....................................................52

5.1: Riscos Contratualmente Alocados à Contratante ....................................54

5.2: Riscos Contratualmente Alocados à Contratada ...................................56

Capítulo 6: Aplicação da Onerosidade Excessiva aos Contratos EPC ............61

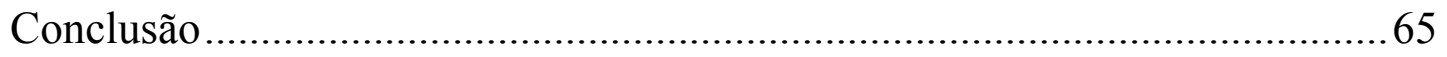

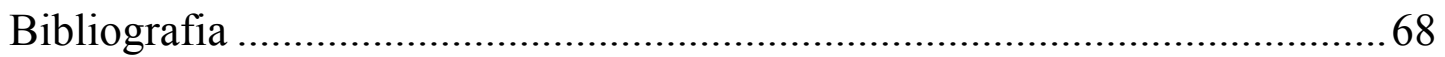




\section{Introdução}

"[...] because contracts are the major means by which one firm interrelates with another firm, or one organization interrelates with the consumer. They are in effect, the neurons of the economic system. Of course, studying the contracts has to be supplemented by a study of the actions of the firms in modifying and interpreting the terms of the contracts"I.

$\mathrm{O}$ ordenamento jurídico brasileiro prevê duas espécies de contrato de construção, quais sejam, a empreitada e a construção por administração ou a preço de custo. Enquanto a empreitada encontra previsão específica no artigo 610 da Lei n. 10.406, de 10 de janeiro de 2002 ("Código Civil”), a construção por administração encontra sua previsão na Lei n. 4.591, de 16 de dezembro de 1964 (“Lei de Incorporações Imobiliárias").

Entretanto, devido às crescentes demandas de infraestrutura no Brasil, as partes contratantes começaram a adotar modelos de contratos de construção que se mostraram eficazes em outros países. Atualmente, temos diversos modelos de contratos de construção que nem sempre são bem estruturados (visto que são frutos da fácil e perniciosa prática de "copia e cola"), que regulam as relações comerciais, técnicas e legais das partes envolvidas no mercado da construção ${ }^{2}$.

Conseguinte, para as obras de grande porte que envolvem projetos complexos de infraestrutura, além do modelo da empreitada, outros modelos tem sido utilizados, como, por exemplo, o Engineering, Procurement and Construction ("Contrato EPC" ou "EPC") Turnkey", que reúne a engenharia, a construção, a compra e montagem de equipamentos, comissionamento e "start

${ }^{1}$ COASE, Ronald. Why Economics Will Change. Comentários proferidos na Universidade de Missouri, Columbia, Missouri, em 4 de abril de 2002. Disponível em: $<\mathrm{http}: / /$ coase.org/coaseremarks2002.htm>. Acesso em 16 de outubro de 2018.

2 MARCONDES, Fernando. Temas de Direito da Construção: Contratos de Construção por Administração com Preço Máximo Garantido: a Lógica Econômica e a Apuração dos Resultados. $1^{\text {a }}$ ed.. São Paulo: Pini, 2015. p. 11.

${ }^{3}$ Modelo criado pela FIDIC (Federação Internacional de Engenheiros e Consultores) e publicado pela entidade, conhecido como "The Silver Book". 
up" do empreendimento, tudo em um único contrato ${ }^{4}$, normalmente figurando como "Epcista", um grupo de empresas sob o regime de consórcio ou subcontratação.

É nesse sentido que o termo em inglês Turnkey é utilizado como sinônimo do Contrato EPC, visto que cabe ao dono da obra, após o recebimento do projeto pelo "Epcista", somente "virar a chave" visto que o empreendimento está em condições de funcionamento imediato.

Sob a modalidade EPC Turnkey, a maior parte dos riscos são contratualmente alocados à contratada, ou, em outras palavras, à "Epcista". Como consequência lógica, permite-se que o "Epcista" inclua em sua proposta de preço e prazo um contingenciamento de verba extra para fazer frente aos elevados riscos que assumirá ${ }^{5}$.

O "Epcista", além de ser responsável pelos riscos ordinários que derivam do Contrato EPC também assume a responsabilidade do desempenho futuro do empreendimento após a entrega da obra em plenas condições de funcionamento. Exemplo disso seria a contratação de uma usina sob a modalidade EPC Turnkey em que o "Epcista" deve atender à premissa que lhe foi informada no início, entregando uma usina capaz de gerar determinada quantidade de energia, sob pena de pagamento de penalidades severas pelo não atingimento da performance ${ }^{6}$.

O presente trabalho visa analisar a possibilidade de incidência do instituto da onerosidade excessiva e consequentemente o pedido de reequilíbrio econômico-financeiro no âmbito dos contratos feitos sob a modalidade EPC Turnkey.

${ }^{4}$ MARCONDES, Fernando. Temas de Direito da Construção: Contratos de Construção por Administração com Preço Máximo Garantido: a Lógica Econômica e a Apuração dos Resultados. $1^{a}$ ed.. São Paulo: Pini, 2015. p. 12.

5 MARCONDES, Fernando. Temas de Direito da Construção: Contratos de Construção por Administração com Preço Máximo Garantido: a Lógica Econômica e a Apuração dos Resultados. $1^{\text {a }}$ ed.. São Paulo: Pini, 2015. p. 12.

6 MARCONDES, Fernando. Temas de Direito da Construção: Contratos de Construção por Administração com Preço Máximo Garantido: a Lógica Econômica e a Apuração dos Resultados. $1^{\text {a }}$ ed.. São Paulo: Pini, 2015. p. 12. 
As condições inicialmente estabelecidas entre as partes contratantes, presumidas como proporcionais, podem tornar-se desequilibradas no transcorrer do tempo. O EPC é um contrato de execução diferida visto que a execução das obras depende de um longo período de tempo para ser concluída. Sendo assim, ambas as partes estão sujeitas a maiores riscos que podem gerar um desequilíbrio econômico-financeiro contratual. As partes contratantes estão sujeitas a riscos de diversas naturezas, como, por exemplo, riscos de ordem técnica, natural, legislativa, cambial, política, etc. Os referidos riscos são contratualmente alocados à contratante e à contratada no Contrato EPC, sendo certo, todavia, que é quase impossível esgotar nas cláusulas contratuais todos os eventos que geram o desequilíbrio econômico-financeiro contratual.

A teoria da imprevisão foi tratada nos artigos 317 e 478 do Código Civil e nos artigos 57 e 65, II, $d$, da Lei n. 8.666, de 21 de junho de 1993 ("Lei de Licitações"). Tais artigos instituíram o conceito da onerosidade excessiva quando presente certos requisitos, permitindo a revisão ou resolução do contrato.

A presente monografia limitou-se a apresentar e analisar a aplicação do instituto da onerosidade excessiva aos contratos EPC, levando em consideração, ainda, os riscos contratualmente alocados às partes contratantes, como maneira de mitigar sua exposição a determinados eventos que geram o desequilíbrio econômico-financeiro e, consequentemente, aos pedidos de revisão de preço e prazo do contrato.

No intuito de alcançar esse objetivo, serão apresentadas, na primeira parte deste estudo, a contextualização histórica e social do Contrato EPC para, no segundo momento, abordar as características deste contrato e como os riscos são contratualmente alocados. No terceiro capítulo, iremos adentrar no instituto da onerosidade excessiva analisando os seus requisitos de aplicação, bem como a legislação pertinente e a posição da jurisprudência internacional. O quarto capítulo é dedicado aos pleitos contratuais feitos pelo dono da obra e 
pelo "Epcista" para se atingir o reequilíbrio econômico-financeiro nos contratos EPC que estão expostos a inúmeros eventos que geram riscos. $\mathrm{O}$ último capítulo é dedicado exclusivamente à aplicação da onerosidade excessiva no Contrato EPC.

O crescimento das complexas obras de infraestrutura no Brasil passam pela necessidade de envolver agentes diversos dentro do mesmo contrato. Esses agentes são os engenheiros, arquitetos, órgãos governamentais, advogados, fornecedores de material, agências financiadoras e topógrafos, entre tantos outros.

Os contratos de modalidade EPC abrangem todos esses agentes e são adotados nos projetos de construção de grande porte, como, por exemplo, a ampliação de aeroportos, construção de parques solares, reformas de estádios e outros empreendimentos.

Diante de todo o exposto, o EPC vem sendo muito utilizado devido às novas exigências de mercado e as políticas públicas de controle de despesas de combate à corrupção que exigem e justificam a adoção de padrões internacionais de contratos, garantindo maior transparência e segurança em sua execução ${ }^{7}$.

\footnotetext{
${ }^{7}$ MARIANGELO, Rafael. Temas de Direito da Construção: Aspectos Relevantes dos Modelos Contratuais FIDIC. 1 ${ }^{\text {a }}$ ed.. São Paulo: Pini, 2015. p. 207.
} 


\title{
Capítulo 1: Contextualização Histórica e Social 1.1. A Evolução do Contrato EPC
}

Os contratos chamados de EPC, nascem na modernidade com o desenvolvimento das obras de engenharia pesada, industrial ou de infraestrutura: desde a construção de plantas químicas, geração elétrica, mineração, até a extração e refinamento de óleo e gás. O EPC diverge da forma tradicional de se celebrar e executar uma obra, em que o dono escolhe um empreiteiro e adquire os bens necessários para a construção, após preparar o projeto, intervindo em todas as etapas do empreendimento para se alcançar o fim unitário (a prestação principal do contrato). Nesse sentido, Marcelo Alencar Botelho de Mesquita afirma:

\begin{abstract}
"Tema dos mais obscuros e controvertidos entre os quais operam com contratos de "construções consideráveis", para usar a expressão legal do Código Civil quando trata das obras de engenharia pesada (art. 618), é o da qualificação do contrato "chave na mão" (turnkey) e do chamado engineering, procurement and construction contract, ou EPC. Por meio desses ajustes, atribui-se a um único contratado - ainda que se trate de consórcio de empresas - praticamente a integralidade das atividades necessárias para implantação de certo empreendimento, desde a concepção até sua operação, englobando projetos, aquisição de materiais e de maquinário, construção de obras, capacitação do pessoal da contratante e colocação em funcionamento das instalações" ${ }^{8}$.
\end{abstract}

O EPC é fruto da industrialização e globalização onde o agente estatal é substituído pela forte presença de capital privado. Nos países em desenvolvimento, como o Brasil, o contrato é visto como a melhor opção para negociação e contratação de obras de infraestrutura frente à ausência do Estado devido ao esgotamento dos recursos públicos em grande parte canalizados para o pagamento das enormes dívidas públicas, tanto interna como externa.

\footnotetext{
${ }^{8}$ MESQUITA, Marcelo Alencar Botelho. Contratos Chave Na Mão (Turnkey) e EPC: Conteúdo e Qualificações. Florianópolis. 2017. 212. Tese (Mestrado). Universidade Federal de Santa Catarina. p. 15.
} 
"As grandes empresas multinacionais passam a se apoiar em contratos também como forma de se eximir das tutelas estatais locais (que, nos casos dos países em desenvolvimento, vêem-se às voltas com o crônico emperramento do Judiciário), empregando cláusulas de eleição de foro e lei aplicável ao contrato, assim como cláusulas de arbitragem, que deslocam a resolução de eventuais conflitos para jurisdições mais "confiáveis", ou teoricamente estáveis"’.

O EPC é um contrato complexo por natureza pois regula diversas atividades interdependentes, no entanto, essas atividades estão enquadradas de forma indivisível para se atingir um resultado específico. Devido à sua complexidade, há certa dificuldade em designar as operações realizadas no EPC e, consequentemente, diversos termos (design-build, turnkey, lumpsum, etc.) dotados do mesmo significado são utilizados para caracterizar o contrato e as suas operações. Entretanto, a partir da análise e evolução do contrato de execução de obra é possível diferenciar os referidos termos e entender a sua relevância.

\subsubsection{Do Método Convencional ao Design-Build}

Antes de analisar historicamente a evolução dos contratos de construção que culmina no EPC, importa ter em mente que todo e qualquer empreendimento é implantado, basicamente, pela realização de duas atividades: a concepção da obra (projeto) e sua execução (construção) ${ }^{10}$.

Até meados do século XIX, os arquitetos e/ou engenheiros detinham a totalidade da responsabilidade pelos riscos do empreendimento (projeto e construção). Após o fim da primeira Revolução Industrial, devido a maior complexidade das construções e aumento de especialização, o primeiro

\footnotetext{
${ }^{9}$ GIL, Fabio Coutinho de Alcântara. A Onerosidade Excessiva em Contratos de Engineering. São Paulo, 2007. 146. Tese (Doutorado). Universidade de São Paulo. p. 13.

${ }^{10}$ MESQUITA, Marcelo Alencar Botelho. Contratos Chave Na Mão (Turnkey) e EPC: Conteúdo e Qualificações. Florianópolis. 2017. 212. Tese (Mestrado). Universidade Federal de Santa Catarina. p. 25.
} 
modelo de contratação de obra foi desenvolvido. O arranjo convencional, também chamado de design then build ou deisgn-bid-build, resulta na autonomia na divisão de tarefas do arquiteto e/ou engenheiro na concepção da obra perante o construtor na execução da obra e/ou fornecimento dos serviços. Desta forma, há a separação da responsabilidade dos projetistas e do construtor.

A divisão de responsabilidade entre a concepção e construção do projeto permite o aumento da concorrência da obra pelo menor preço, com maior objetividade e igualdade, enquanto, para a contratação do projetista, fazse necessário levar em conta também a qualidade da solução técnica ${ }^{11}$.

\begin{abstract}
"Nos modelos de contratação tradicional, conhecidos no Brasil como contratos de empreitada, o órgão público envolve um ente privado na concepção e outro na execução da obra ou no fornecimento dos serviços. O autor do projeto não pode participar da execução da obra, o financiamento é obtido diretamente pelo órgão competente, e o pagamento pela execução do projeto se dá, normalmente, contra a entrega" 12 .
\end{abstract}

Como consequência do sofisticação e complexidade das construções em paralelo ao surgimento do arranjo convencional há a criação de um novo modelo de contratação de obras, concentrando as diversas atividades e responsabilidade nas mãos de um único contratado (general contractor). Sendo assim, o empreiteiro assumiu uma postura empresarial responsável pela gestão das atividades.

O método tradicional de contratação de obras apresentava problemas, pois além dos arquitetos e engenheiros não serem responsáveis pela execução do empreendimento, estes não empregavam a melhor técnica, tendo em vista

\footnotetext{
${ }^{11}$ MESQUITA, Marcelo Alencar Botelho. Contratos Chave Na Mão (Turnkey) e EPC: Conteúdo e Qualificações. Florianópolis. 2017. 212. Tese (Mestrado). Universidade Federal de Santa Catarina. p. 30 .

${ }^{12}$ GRIZENDI, Eduardo; GRILO, Leonardo M.; PAIVA, Ricardo N.; ALVES, Rubens; e RUSSO, Waldo A. PPP - Parcerias Público-Privadas - Experiência Internacional no Setor Aeroespacial. Rio de Janeiro: E-papers Serviços Editoriais Ltda., 2011. p. 27.
} 
que não tinham conhecimento dos aspectos construtivos. A divisão de responsabilidade pelas obras gerava um "empurra-empurra" entre projetista e construtor, aumentando as chances de ocorrência de litígios.

"Do ponto de vista do planejamento, pelo sistema tradicional, não se iniciava a construção ou as compras de material previamente ao término dos projetos, vez que não se sabia a extensão das obra e serviços, sem o que não se podia contrata $o$ construtor por um preço fixo" ${ }^{\text {13 }}$.

Em busca de maior eficiência e como continuidade da responsabilidade alocada na figura do construtor surge o design-build. Nesse tipo de contratação, o construtor fica responsável por incumbências antes reservadas a outros profissionais, o que também ocorre no turnkey e EPC. Todavia, o design-build possui características próprias que o diferenciam dos outros tipos de contratação.

Como o design-build reúne na figura da mesma pessoa a concepção e execução do empreendimento, há a possibilidade da construção se iniciar antes do término do projeto resultando na redução do prazo total das obras, dado que o construtor, com o preço estabelecido de antemão, já prepara os desenhos e inicia as obras.

"Outra vantagem do método estaria em que, aliados aos construtores, os projetistas
poderiam aproveitar as tecnologias mais avançadas detidas por estes, com ganhos de
preço e prazo por conta da incorporação da experiência construtiva nos desenhos,
além de viabilizar as contratações em que somente o construtor possua a capacidade
para elaborar os projetos" "14.
O regime de preço estipulado no design-build é o global onde o

${ }^{13}$ MESQUITA, Marcelo Alencar Botelho. Contratos Chave Na Mão (Turnkey) e EPC: Conteúdo e Qualificações. Florianópolis. 2017. 212. Tese (Mestrado). Universidade Federal de Santa Catarina. p. 33.

${ }^{14}$ MESQUITA, Marcelo Alencar Botelho. Contratos Chave Na Mão (Turnkey) e EPC: Conteúdo e Qualificações. Florianópolis. 2017. 212. Tese (Mestrado). Universidade Federal de Santa Catarina. p. 40. 
contratante tem certeza do preço da obra, considerando que o principal fator de modificação costuma residir nas alterações do projeto, aqui concentrado no próprio contratado.

Todavia, a maior característica do design-build é o ponto único de responsabilidade (single point responsibility) onde atribui-se a um único agente a responsabilidade pelos projetos e execução das obras. A contratada, ou "Epcista", deverá entregar o projeto quando este estiver operacional de acordo com as especificações da contratante; qualquer defeito ou inadimplemento é necessariamente de sua responsabilidade, exceto quando o contrato determinar o contrário. Devido ao ponto único de responsabilidade, as reivindicações diminuem e há aumento da facilidade de identificar o causador de eventuais vícios nas obras.

\subsubsection{Do Design-Build ao Turnkey}

A compreensão dos 'contratos chave na mão', também conhecidos como turnkey, é de suma importância para posteriormente analisar o Contrato EPC, inclusive porque grande parte da doutrina não consegue enxergar a diferença entre esses modelos.

De forma parecida com o design-build, nos contratos turnkey o construtor também fica obrigado e responsável pelos projetos da obra, motivo pelo qual alguns autores consideram não passar esse ajuste da denominação norte-americana ao design-build ${ }^{15}$. Inclusive, nessa forma de contratação, também há a existência do ponto único de responsabilidade pelos projetos e sua execução.

\footnotetext{
${ }^{15}$ MESQUITA, Marcelo Alencar Botelho. Contratos Chave Na Mão (Turnkey) e EPC: Conteúdo e Qualificações. Florianópolis. 2017. 212. Tese (Mestrado). Universidade Federal de Santa Catarina. p. 44.
} 
Conquanto exista quem considere o turnkey um tipo puro de designbuild $^{16}$, o contrato chave na mão é uma evolução deste último pois concentra maior responsabilidade nas mãos do construtor, visto que além de toda a atividade material de execução (direta e indireta), o contratado assume integral responsabilidade de entregar o empreendimento equipado, testado e pronto para funcionar. Pelas características expostas, o turnkey pode ser considerado uma evolução e aperfeiçoamento do design-build, onde há a responsabilidade de entrega da construção completa, equipada e operacional, bastando "virar a chave" para que tudo funcione ${ }^{17}$.

No Brasil, o contrato turnkey, também conhecido como modelo integrado com operação, é usado no mercado privado de obras industriais, onde o ente privado responde pela concepção, construção ou montagem, comissionamento e, em alguns casos, operação inicial do projeto, transferida posteriormente ao contratante ${ }^{18}$.

A partir do turnkey, os modelos de contratação dos serviços de engenharia do common law passam a ser adotados na esfera internacional tornando-se um padrão de contratação.

\subsubsection{Do Turnkey ao EPC}

Tanto o turnkey como o design build possuem características que estão presentes no Contrato EPC, surgido no momento em que os empreendimentos passaram a ser assumidos pelos particulares e não mais pelo Poder Público por meio de financiamentos.

\footnotetext{
${ }^{16}$ MESQUITA, Marcelo Alencar Botelho. Contratos Chave Na Mão (Turnkey) e EPC: Conteúdo e Qualificações. Florianópolis. 2017. 212. Tese (Mestrado). Universidade Federal de Santa Catarina. p. 45.

${ }^{17}$ MESQUITA, Marcelo Alencar Botelho. Contratos Chave Na Mão (Turnkey) e EPC: Conteúdo e Qualificações. Florianópolis. 2017. 212. Tese (Mestrado). Universidade Federal de Santa Catarina. p. 45.

${ }^{18}$ GRIZENDI, Eduardo; GRILO, Leonardo M.; PAIVA, Ricardo N.; ALVES, Rubens; e RUSSO, Waldo A. PPP - Parcerias Público-Privadas - Experiência Internacional no Setor Aeroespacial. Rio de Janeiro: E-papers Serviços Editoriais Ltda., 2011. p. 27.
} 
Esse novo modelo de contratação chamado de project finance foi desenvolvido a partir das décadas de 1960 e 1970, passando a vigorar internacionalmente.

As grandes obras precisavam gerar lucro, ao menos em parte, devendo ser financeira e economicamente viáveis de forma independente, a fim de pagar os financiadores e prover benefício econômico aos desenvolvedores ${ }^{19}$.

Atribui-se ao construtor não somente as atividades de implantação do empreendimento, como também a assunção dos riscos, de modo a proteger ao máximo o contratante (e os financiadores) e eliminar, tanto quanto possível, variações no preço e no prazo, ou a falta de desempenho das obras ${ }^{20}$.

A contratada assume a elaboração do projeto de obra de determinado empreendimento, geralmente de infraestrutura ou indústria vultosa, a execução desse empreendimento para sua entrega em plenas condições de operar (daí, como já mencionado, a expressão turnkey), passando também pela etapa do suprimento de insumos e materiais - incluindo equipamentos, maquinário e outras instalações que o empreendimento exija - necessários à perfeita operação do projeto, além da nova alocação de riscos, surgindo, assim, o Contrato EPC.

“O preço e o prazo imutáveis seriam exigências de mercado, e o EPC a resposta às tendências de desenvolvimento de instalações e de infraestrutura por meio de projetos financiados (project finance), representando uma evolução dos contratos chave na mão, com todas as suas prestações mas diferente alocação de riscos"21.

\footnotetext{
${ }^{19}$ MESQUITA, Marcelo Alencar Botelho. Contratos Chave Na Mão (Turnkey) e EPC: Conteúdo e Qualificações. Florianópolis. 2017. 212. Tese (Mestrado). Universidade Federal de Santa Catarina. p. 54.

${ }^{20}$ MESQUITA, Marcelo Alencar Botelho. Contratos Chave Na Mão (Turnkey) e EPC: Conteúdo e Qualificações. Florianópolis. 2017. 212. Tese (Mestrado). Universidade Federal de Santa Catarina. p. 57.

${ }^{21}$ MESQUITA, Marcelo Alencar Botelho. Contratos Chave Na Mão (Turnkey) e EPC: Conteúdo e Qualificações. Florianópolis. 2017. 212. Tese (Mestrado). Universidade Federal de Santa Catarina. p. 57.
} 
O modelo EPC também é fruto da criação feita pelas minutas modelo da Fédération Internationale des Ingénierus Conseils ("FIDIC"), editadas a partir de 1990.

É importante ressaltar que grande parte da doutrina entende que não há distinções entre os modelos turnkey e EPC, e, consequentemente, utilizam as expressões até como sinônimas. No entanto, se alguma diferença pode ser apontada entre os referidos contratos, seria que o EPC foi desenvolvido para o financiamento de projetos com a exigência de maior certeza quanto ao preço, prazo e desempenho ajustados. O Contrato EPC é uma evolução dos modelos expostos acima, visto que além de conter todas as suas características, contém também a certeza do preço, prazo e a assunção dos riscos.

É certo que o Contrato EPC foi elaborado para o financiamento de projetos, no entanto, tal modelo ganhou popularidade, haja vista a grande vantagem, buscada por todos os donos de obra, de ter superior previsibilidade quanto ao valor final do empreendimento ${ }^{22}$. O Contrato EPC é usado, atualmente, sempre que a contratante busca um modelo de contratação que inclua garantias de preço, prazo e qualidade de desempenho.

Hoje, modelos EPC com maior alocação de riscos sobre o construtor são utilizados indiscriminadamente, sempre que o contratante busque uma solução global com garantias de que o preço, qualidade e prazo serão atendidos ${ }^{23}$.

\footnotetext{
${ }^{22}$ MESQUITA, Marcelo Alencar Botelho. Contratos Chave Na Mão (Turnkey) e EPC: Conteúdo e Qualificações. Florianópolis. 2017. 212. Tese (Mestrado). Universidade Federal de Santa Catarina. p. 61.

${ }^{23}$ MESQUITA, Marcelo Alencar Botelho. Contratos Chave Na Mão (Turnkey) e EPC: Conteúdo e Qualificações. Florianópolis. 2017. 212. Tese (Mestrado). Universidade Federal de Santa Catarina. p. 61-62.
} 


\section{Capítulo 2: O Contrato EPC no Direito Brasileiro 2.1. O Contrato EPC e a Empreitada}

Como já descrito acima, no direito privado brasileiro, a execução das obras é disciplinada pelo Código Civil e pela Lei de Incorporações Imobiliárias. Enquanto o Código Civil dispõe sobre o contrato de empreitada, a Lei de Incorporações Imobiliárias rege as particularidades da construção imobiliária de edificações em condomínio. No entanto, é no Código Civil que encontramos as regras que estabelecem a contratação e execução de obras entre particulares, ou seja, a empreitada.

A empreitada pode ser definida como um contrato no qual uma parte se obriga a executar certa obra, determinada ou determinável, com independência econômica e sob o próprio risco, mediante remuneração da outra ${ }^{24}$. No entanto, em sua definição essencialmente civil, a empreitada é o negócio jurídico pelo qual o empreiteiro se obriga a entregar determinado projeto em contrapartida a um preço que deverá ser pago pelo proprietário.

"Uma vez que o contrato de EPC é uma criação estrangeira, aplica-lo à legislação brasileira acarreta numa busca natural por enquadramento jurídico adequado. A análise mais comum é conceituar o EPC como forma do contrato de empreitada ou que o PC cabe dentro da empreitada. Segundo estas visões, o EPC guardaria as características do contrato de empreitada regulado pelo Código Civil Brasileiro em seus artigos 610 a $626^{\prime 25}$.

Parte da doutrina entende que o Contrato EPC pode ser visto como um tipo de empreitada enquanto a outra parte qualifica o referido contrato como

\footnotetext{
${ }^{24}$ MESQUITA, Marcelo Alencar Botelho. Contratos Chave Na Mão (Turnkey) e EPC: Conteúdo e Qualificações. Florianópolis. 2017. 212. Tese (Mestrado). Universidade Federal de Santa Catarina. p. 73.

${ }^{25}$ GOZZI, Elcio Fagundes Marques. Contrato EPC (Engineering, Procurement e Construction) e o Padrão FIDIC. São Paulo. 2016. 94. Tese (Mestrado). Escola de Direito de São Paulo da Fundação Getúlio Vargas. p. 18.
} 
atípico. Os contratos atípicos são aqueles que não tem um modelo típico disposto em $1 \mathrm{ei}^{26}$. A atipicidade está prevista no artigo 425 do Código Civil:

“Art. 425. É lícito às partes estipular contratos atípicos, observadas as normas gerais fixadas neste Código",27.

A parte da doutrina que considera o EPC atípico também entende que enquadrar o EPC à empreitada pela "atividade preponderante" não corresponderia ao que existe na prática e desconsideraria os diversos papéis que desempenha o $\mathrm{EPC}^{28}$.

Com base nas informações acima descritas, é possível considerar que a empreitada e o EPC possuem vários pontos em comum, no entanto, as características que os diferenciam são mais importantes do que as características que o aproximam, conforme tabela comparativa abaixo:

Tabela 1: Comparativo entre contratos de empreitada e EPC Lump Sum Turnkey.

\begin{tabular}{|l|l|l|}
\hline \multicolumn{1}{|c|}{ Tópico } & \multicolumn{1}{|c|}{ Empreitada } & \multicolumn{1}{|c|}{ EPC Lump Sum Turnkey } \\
\hline Material & $\begin{array}{l}\text { Material opcional (art. } \\
610) .\end{array}$ & Material incluído. \\
\hline Projeto & $\begin{array}{l}\text { Projeto sem execução } \\
\text { obrigatória (art. 610, } \\
\S 2) .\end{array}$ & $\begin{array}{l}\text { Projeto com execução } \\
\text { obrigatória. }\end{array}$ \\
\hline Alteração do Projeto & $\begin{array}{l}\text { Alterações, em regra, } \\
\text { dependem da } \\
\text { autorização do dono } \\
\text { da obra. }\end{array}$ & $\begin{array}{l}\text { Alterações de projeto que } \\
\text { não reflitam em preço e } \\
\text { performance não interferem } \\
\text { no contrato. }\end{array}$ \\
\hline Risco de Execução & $\begin{array}{l}\text { Risco por conta do do } \\
\text { dono da obra em }\end{array}$ & $\begin{array}{l}\text { Risco do "Epcista", salvo } \\
\text { disposição específica. }\end{array}$ \\
\hline
\end{tabular}

${ }^{26}$ GOZZI, Elcio Fagundes Marques. Contrato EPC (Engineering, Procurement e Construction) e o Padrão FIDIC. São Paulo. 2016. 94. Tese (Mestrado). Escola de Direito de São Paulo da Fundação Getúlio Vargas. p. 26.

${ }^{27}$ Lei n. 10.406, de 10 de janeiro de 2002. Código Civil. Artigo 425.

${ }^{28}$ MESQUITA, Marcelo Alencar Botelho. Contratos Chave Na Mão (Turnkey) e EPC: Conteúdo e Qualificações. Florianópolis. 2017. 212. Tese (Mestrado). Universidade Federal de Santa Catarina. p. 173. 


\begin{tabular}{|c|c|c|}
\hline & $\begin{array}{l}\text { fornecimento de mão } \\
\text { de obra (art. 612). }\end{array}$ & \\
\hline Aceite da Obra & $\begin{array}{l}\text { Tudo o que se pagou } \\
\text { presume-se verificado } \\
\text { (art. } 614, \S 1) \text {. }\end{array}$ & $\begin{array}{l}\text { Aceite depende do } \\
\text { atendimento da formalidade } \\
\text { contratual: resultado. }\end{array}$ \\
\hline $\begin{array}{l}\text { Denúncia de Vícios e } \\
\text { Defeitos }\end{array}$ & $\begin{array}{l}30 \text { dias após a } \\
\text { medição da obra (art. } \\
614, \S 2) .\end{array}$ & $\begin{array}{l}\text { Depende de estipulação das } \\
\text { partes. Raramente é menor } \\
\text { do que } 12 \text { meses. }\end{array}$ \\
\hline $\begin{array}{l}\text { Entrega / Recebimento } \\
\text { do Objeto Contratual }\end{array}$ & $\begin{array}{l}\text { Após a conclusão da } \\
\text { obra: ajuste contratual } \\
\text { ou usos e costumes } \\
\text { (art. 615). }\end{array}$ & $\begin{array}{l}\text { Atendimento da finalidade } \\
\text { do projeto: resultado. }\end{array}$ \\
\hline $\begin{array}{l}\text { Responsabilidade Pós- } \\
\text { Obra }\end{array}$ & $\begin{array}{l}\text { Empreiteiro } \\
\text { responderá por } \\
\text { solidez e segurança } \\
\text { por } 5 \text { anos após o } \\
\text { termino da obra (arts. } \\
618 \text { e 622). }\end{array}$ & $\begin{array}{l}\text { O "Epcista" responde além } \\
\text { da solidez, também pelo } \\
\text { desempenho } \\
\text { empreendimento. }\end{array}$ \\
\hline Preço & 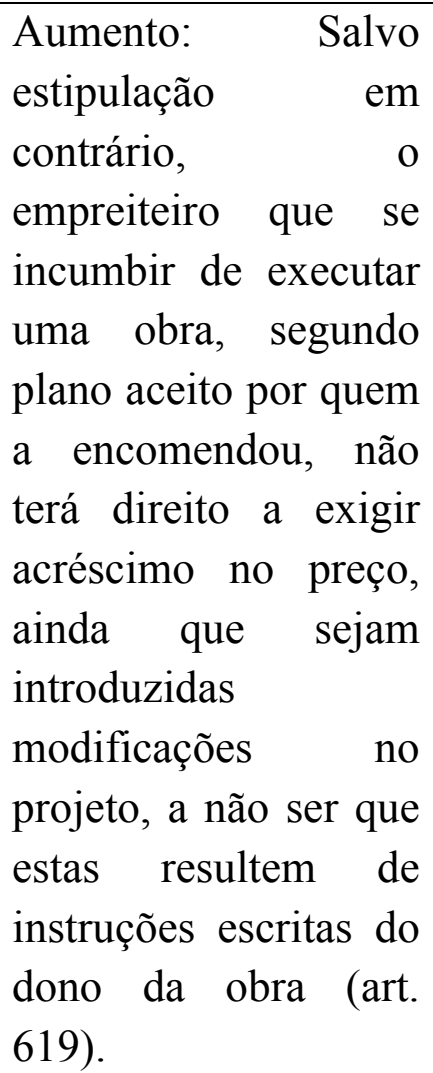 & $\begin{array}{l}\text { Fixo, como condição } \\
\text { essencial do contrato. }\end{array}$ \\
\hline
\end{tabular}




\begin{tabular}{|c|c|c|}
\hline & $\begin{array}{l}\text { Redução: Se ocorrer } \\
\text { diminuição no preço } \\
\text { do material ou da } \\
\text { mão-de-obra superior } \\
\text { a um décimo do preço } \\
\text { global } \\
\text { convencionado, } \\
\text { poderá este ser } \\
\text { revisto, a pedido do } \\
\text { dono da obra, para } \\
\text { que se lhe assegure a } \\
\text { diferença apurada (art. } \\
620 \text { ). }\end{array}$ & \\
\hline $\begin{array}{l}\text { Rescisão Unilateral } \\
\text { Imotivada do Contrato }\end{array}$ & $\begin{array}{l}\text { Pelo dono da obra: } \\
\text { deve ao empreiteiro } \\
\text { indenização e lucros } \\
\text { cessantes (art. 623). } \\
\text { Pelo empreiteiro: } \\
\text { responde por perdas e } \\
\text { danos ao dono da obra } \\
\text { (art. 624). }\end{array}$ & $\begin{array}{l}\text { Pelo dono da obra: } \\
\text { reembolso de despesas, } \\
\text { trabalhos realizados e multa } \\
\text { contratual de caráter } \\
\text { indenizatório/compensatório. } \\
\text { Não há unanimidade sobre } \\
\text { lucros cessantes e perdas e } \\
\text { danos. } \\
\text { Pelo empreiteiro: perda das } \\
\text { garantias contratuais em } \\
\text { favor do dono da obra, } \\
\text { reembolso de despesas e } \\
\text { multa contratual de caráter } \\
\text { indenizatório/compensatório. } \\
\text { Não há unanimidade sobre } \\
\text { lucros cessantes e perdas e } \\
\text { danos. }\end{array}$ \\
\hline
\end{tabular}

Fonte: Tese de Mestrado de Elcio Fagundes Marques Gozzi. Contrato EPC (Engineering, Procurement e Construction) e o Padrão FIDIC. 2016. p. 27.

Resta claro que nenhum dispositivo legal trata com certeza e clareza sobre Contrato EPC. José Emílio Nunes Pinto, ao examinar a questão das 
semelhanças gritantes entre a empreitada e o Contrato EPC, chega a seguinte conclusão:

"O enquadramento dessa série complexa de papéis desempenhados pelo epcista no marco da empreitada é amesquinhar o escopo da relação jurídica existente entre este e o contratante. Equivaleria enquadrar o contrato num tipo legal com base na atividade mais preponderante no complexo de todas as atividades, criando-se uma distinção internamente ao contrato que não corresponde ao que existe na prática. Dessa forma, estaríamos ignorando que as obrigações assumidas pelas partes no EPC somente serão consideradas cumpridas quando o epcista tenha desempenhado seus diversos papéis, o que irá além do cumprimento das obrigações previstas na empreitada pura e simples" ${ }^{29}$.

Aos que julgam ser o EPC um contrato atípico, entendem que a empreitada não comportaria as múltiplas atividades próprias de uma obra complexa ou o agravamento dos riscos contratuais característicos do $\mathrm{EPC}^{30}$. Ou seja, o enquadramento do Contrato EPC no modelo de empreitada não é a melhor saída pois as regras da empreitada se mostram incapazes de regular o complexo arranjo contratual do EPC.

A dificuldade de classificação e qualificação do Contrato EPC é evidente, sendo necessária uma análise dos seus principais elementos constitutivos.

\subsection{Classificação do Contrato EPC}

Com o intuito de classificar o Contrato EPC temos que analisar seus elementos constitutivos devido à sua enorme complexidade ao reunir diversas funções. Cavallo Borgia evidencia tal complexidade:

\footnotetext{
${ }^{29}$ PINTO, José Emílio Nunes. O contrato EPC para construção de grandes obras de engenharia e o novo Código Civil. Disponível em $<$ http://jus.com.br/artigos/2806/o-contrato-de-epc-para-construcaode-grandes-obras-de-engenharia-e-o-novo-codigo-civil $>$. Acesso em 24 de setembro de 2018.

${ }^{30}$ MESQUITA, Marcelo Alencar Botelho. Contratos Chave Na Mão (Turnkey) e EPC: Conteúdo e Qualificações. Florianópolis. 2017. 212. Tese (Mestrado). Universidade Federal de Santa Catarina. p. 190.
} 
"Resulta da integração de várias disciplinas de engenharia e arquitetura, bem como financeira e administrativa. Ressalta também que a qualidade do sujeito contratante, que deve ser dotado de formação técnica apropriada, é traço distintivo importante deste contrato. No entanto, mais um elemento figura na caracterização desse contrato, qual seja, a presença do risco na consecução do objeto. Esses três elementos, complexidade, risco e qualificação da parte contratada são essenciais à qualificação contratual, muito embora não sejam independentes ou autônomos entre si, mas antes mutuamente indutores, ora com pesos similares, ora com peso diferentes entre si, na composição não só do regulamento contratual, mas também durante o iter de sua execução"31.

\subsubsection{Contrato Empresarial}

O Contrato EPC é empresarial visto que ambos (ou, conforme o caso, todos) os pólos da relação jurídica-contratual têm a sua atividade movida por razões empresariais.

O aspecto empresarial atribui características próprias e viés peculiar aos contratos empresariais, que, naturalmente, os distinguem dos contratos em outros segmentos do Direito. O artigo 966 do Código Civil define empresário como aquele que "exerce profissionalmente atividade econômica organizada para a produção e circulação de bens ou de serviços" ${ }^{, 32}$.

O empresário certamente apresenta mais condições para contratar especialistas em engenharia, contabilidade, economia, direito, entre outros, para assisti-lo na negociação e compreensão dos termos e condições do contrato $^{33}$.

Isto posto, o EPC certamente se distingue de um contrato de comum de construção por caracterizar-se como instrumento empresarial com fins produtivos.

\footnotetext{
${ }^{31}$ GIL, Fabio Coutinho de Alcântara. A Onerosidade Excessiva em Contratos de Engineering. São Paulo. 2007. 143. Tese (Doutorado). Universidade de São Paulo. p. 27.

${ }_{33}^{32}$ Lei n. 10.406, de 10 de janeiro de 2002. Código Civil. Artigo 966.

${ }^{33}$ CHEN, Daniel Shem Cheng. Contrato de Engineering. Disponível em: <http://www.ambitojuridico.com.br/site/?n_link=revista_artigos_leitura\&artigo_id=12257>. Acesso em 17 de outubro de 2018.
} 
"Assim, enquanto um contrato de empreitada pode ser celebrado para operações envolvendo desde consumidores até empresários, o âmbito do chave na mão e do EPC estaria circunscrito aos negócios entre grandes corporações objetivando a exploração de recursos naturais e o uso de bens de capital". ${ }^{44}$

\subsubsection{Contrato Bilateral}

Muito embora o Contrato EPC seja celebrado por apenas duas partes, quais sejam, o dono da obra que contrata com consórcio de empresas ou empresa de engenharia especializada; a bilateralidade não se refere à quantidade de partes contratantes. A bilateralidade do EPC se configura na medida que envolve prestações recíprocas de ambas as partes.

A Contratante deve pagar o preço acordado enquanto o "Epcista" deve entregar o projeto em perfeitas condições operacionais, bastando "virar a chave" para dar início às atividades.

\subsubsection{Contrato Consensual e Não Solene}

O Contrato EPC é consensual, uma vez que depende apenas da válida e adequada manifestação de vontade das partes contratantes. Ainda, o EPC é não solene pois não existe forma especial e prescrita em lei para a declaração de vontade das partes na celebração do contrato, o que seria contraditório, tendo em vista que não há sequer expressa previsão legal em nossa legislação pátria sobre o referido contrato.

No entanto, o EPC não é formalizado verbalmente devido à sua enorme complexidade. Inclusive, a maioria dos contratos dessa natureza geram conflitos entre as partes, e, consequentemente, o EPC é sempre escrito para facilitar a comprovação das obrigações pactuadas em futuras disputas.

\footnotetext{
${ }^{34}$ MESQUITA, Marcelo Alencar Botelho. Contratos Chave Na Mão (Turnkey) e EPC: Conteúdo e Qualificações. Florianópolis. 2017. 212. Tese (Mestrado). Universidade Federal de Santa Catarina. p. 113.
} 


\subsubsection{Contrato Comutativo}

O EPC é contrato comutativo porque as obrigações são conhecidas no momento da conclusão da avença (embora nada impeça que as partes o estabeleçam de forma aleatória) $)^{35}$, no entanto, as prestações certas e determinadas das partes estão sujeitas a eventuais mudanças decorrentes de fatos externos à vontade inicial ou devido a alterações no projeto de engenharia.

O dono da obra possui a obrigação de pagar o preço acordado, que em geral toma três formas, quais sejam, preço global (lump sum), preço por administração (cost-reiumbursable) e preço por unidade de medida, como veremos no Capítulo 3. Há inúmeras formas do pagamento ser feito pelo dono da obra, desde pagamento em uma única parcela, parcelas fixas ou variáveis atreladas ao alcance de determinadas etapas do projeto - também conhecida como milestones até as prestações que são devidas em datas pré-determinadas ou pré-marcadas. O "Epcista" possui a obrigação certa e determinada de entregar o empreendimento pronto para funcionar.

\subsubsection{Contrato Principal}

O Contrato EPC é considerado principal e não acessório pois sua validade e eficácia não dependem da celebração de qualquer outro contrato ${ }^{36}$. Já os contratos de garantia são acessórios ao EPC, uma vez que somente existem em decorrência deste.

\footnotetext{
${ }^{35}$ GOZZI, Elcio Fagundes Marques. Contrato EPC (Engineering, Procurement e Construction) e o Padrão FIDIC. São Paulo. 2016. 94. Tese (Mestrado). Escola de Direito de São Paulo da Fundação Getúlio Vargas. p. 20.

${ }^{36}$ CHEN, Daniel Shem Cheng. Contrato de Engineering. Disponível em: $<\mathrm{http} / / / \mathrm{www}$.ambitojuridico.com.br/site/?n_link=revista_artigos_leitura\&artigo_id=12257>. Acesso em 21 de outubro de 2018.
} 


\subsubsection{Contrato Pessoal}

$\mathrm{O}$ aspecto pessoal relaciona-se com a alta qualificação técnica exigida por parte do contratado, o que limita sobremaneira as possibilidades de escolha pelo contratante ${ }^{37}$. Geralmente, as companhias formam processos de concorrência para, dentre as empresas de engenharia habilitadas, escolherem a que contempla às necessidades peculiares e específicas do empreendimento. Inúmeros fatores são avaliados e não somente o preço oferecido.

Os diversos fatores levados em conta incluem o relacionamento das empresas de engenharia com os fornecedores de materiais e equipamentos, assim como, a experiência e conhecimento técnico que as empresas concorrentes possuem para realizar aquele tipo específico de obra. Além do mais, outro critério observado pelas companhias é a capacidade que as empresas possuem de atender às imposições estabelecidas pelos financiadores, como, por exemplo, é o caso das exigências locais determinadas pelo Banco Nacional de Desenvolvimento Econômico e Social para a concessão de financiamento em determinadas atividades industriais.

\subsubsection{Contrato de Execução Diferida}

Um dos principais elementos do Contrato EPC é o seu decurso ao longo do tempo, visto que é impossível a execução das obrigações pactuadas pelas partes de forma instantânea.

A execução continuada no tempo ganha notoriedade quando associada à complexidade envolvida nos empreendimentos, pois as obras de infraestrutura de grande porte podem durar anos até serem efetivamente concluídas.

${ }^{37}$ CHEN, Daniel Shem Cheng. Contrato de Engineering. Disponível em: <http://www.ambitojuridico.com.br/site/?n_link=revista_artigos_leitura\&artigo_id=12257>. Acesso em 21 de outubro de 2018. 
Como resultado, se torna evidente a exposição das partes contratantes aos mais diversos riscos, desde os eventos adversos da natureza até as mudanças legislativas. Sendo assim, faz-se necessário uma inteligente alocação contratual de riscos nos Contratos EPC. 


\section{Capítulo 3: Preço e Prazo}

$\mathrm{O}$ assunto do reequilíbrio econômico-financeiro dos contratos EPC ocupa um lugar de extrema importância na elaboração dos contratos pois é necessário estabelecer um alto nível de certeza jurídica sobre as principais variáveis comerciais do projeto, acima de tudo, preço e prazo ${ }^{38}$.

Durante a elaboração e a negociação do Contrato EPC, tendo em vista a posição do dono da obra, ou, em outras palavras, da contratante, o preço e prazo do projeto são premissas cruciais na viabilidade comercial de determinado empreendimento. As variações substanciais de preço e do prazo podem significar a viabilidade de um empreendimento, ou não, seja porque podem adiar a geração de caixa do empreendimento, seja porque podem aumentar o custo de implementação, reduzindo a chamada "taxa interna de retorno" do investimento ${ }^{39}$. Outra característica de suma importância é saber se o projeto terá seus recursos financeiros disponibilizados por um único empreendedor ou se será financiado por instituições financeiras. Como já exposto acima, o preço e o prazo são relevantes para financiamentos, já que a principal garantia do financiador é o lucro do projeto.

Quando não há certeza jurídica quanto ao preço e ao prazo do projeto, faz-se necessário estabelecer outras garantias ao financiador ou aumentar o custo do financiamento por meio de taxas de juros.

\footnotetext{
"Daí por que algumas instituições financeiras já solicitam a adoção de modelos específicos de contrato, como é o exemplo do Banco Mundial, que, em suas operações de financiamento, procura recomendar a utilização dos modelos de contrato elaborado pela FIDIC - Federátion Internationale des Ingénieurs Conseils, em especial o modelo constante do chamado Silver Book, que traz condições para contratação de EPC / Turnkey na modalidade de preço global (Lump Sum)"40.
}

38 SILVA, Leonardo Toledo da. Direito e Infraestrutura. Disponível em: < https://books.google.com.br/books?isbn=8502130749>. Acesso em 08 de novembro de 2018.

39 SILVA, Leonardo Toledo da. Direito e Infraestrutura. Disponível em: < https://books.google.com.br/books?isbn=8502130749>. Acesso em 29 de setembro de 2018.

40 SILVA, Leonardo Toledo da. Direito e Infraestrutura. Disponível em: < https://books.google.com.br/books?isbn=8502130749>. Acesso em 29 de setembro de 2018. 
A contratante e a contratada estabelecem em conjunto o preço e o prazo que são de extrema importância nas fases de negociação e estruturação do Contrato EPC. Essas premissas serão previamente definidas para se obter a viabilidade financeira do empreendimento, e a estrutura contratual do EPC nasce como um resultado da necessidade da precisão do preço e do prazo.

\subsection{Ponto Único de Responsabilidade}

Uma dos principais aspectos do Contrato EPC é o ponto único de responsabilidade (single point responsibility) que busca a viabilidade e financiabilidade dos empreendimentos, através da definição do preço e prazo, através de uma alocação eficiente e efetiva de riscos.

Os riscos que antes eram atribuídos à contratante são alocados à contratada e "Epcista". Devido à alocação de riscos em uma única pessoa, a empresa contratada passa a ser responsável por todos os fornecimentos que são necessários para a implantação e operação do empreendimento.

$\mathrm{O}$ ponto único de responsabilidade pode ser entendido através da concepção de escopo e fornecimento (procurement).

A primeira perspectiva ocorre quando um único agente é responsável pelo escopo para a implementação do empreendimento, ou seja, esse único agente é responsável pela fase de engenharia e suprimento até a total construção, montagem (quando for o caso) e o início da operação do empreendimento, em conformidade com os requisitos técnicos de qualidade, segurança e desempenho estabelecidos ${ }^{41}$. O objetivo principal da perspectiva do escopo é evitar que falhas na fase de implantação, principalmente falhas na fase de engenharia, afetem as fases seguintes, que são intrinsicamente ligadas

41 SILVA, Leonardo Toledo da. Direito e Infraestrutura. Disponível em: < https://books.google.com.br/books?isbn=8502130749>. Acesso em 29 de setembro de 2018. 
à fase de engenharia e, como consequência, afetem o cronograma de implantação das fases seguintes.

Diante da perspectiva de fornecimento, a contratada "Epcista" assume a responsabilidade das compras de insumos como se ela própria estivesse fornecendo os insumos, enquanto, na verdade, os insumos são disponibilizados pelos fornecedores. A responsabilidade de fornecimento é alocado na figura da contratada para evitar que haja divergências acerca de quem arca com a responsabilidade no caso de falha de fornecimento de insumos. Independentemente de a culpa de um fornecimento inadequado não ser diretamente atribuível ao pessoal contratado pelo "Epcista", este arcará, do mesmo modo, com o ônus contratual do fornecimento inadequado ${ }^{42}$. A responsabilidade por eventual falha no fornecimento de insumos por qualquer dos fornecedores associados à implantação do empreendimento é da contratada, no entanto, a mesma é remunerada pela assunção de riscos.

O ponto único de responsabilidade é assumido pela contratada quando há o estabelecimento de disposições contratuais no Contrato EPC. Muitas negociações contratuais adaptam, relativizam ou afastam o ponto único de responsabilidade, tano sob a perspectiva do escopo, quanto sob a perspectiva dos fornecimentos de insumo ligados ao empreendimento. No entanto, é fato notório que o afastamento total do ponto único de responsabilidade desconfigura o Contrato EPC e pode ser fundamento de pleitos bem-sucedidos pela contratada contra a contratante nos casos de disputas por rescisão do EPC.

Ainda, é importante esclarecer que apesar da contratante abraçar diversas responsabilidades, ela celebra inúmeros subcontratos com empresas especializadas. $\mathrm{O}$ mesmo ocorre no contrato de empreitada.

\footnotetext{
42 SILVA, Leonardo Toledo da. Direito e Infraestrutura. Disponível em: < https://books.google.com.br/books?isbn=8502130749>. Acesso em 29 de setembro de 2018 .
} 
Dessa forma, na empreitada, o faturamento direto pode ser pelas subcontratadas à contratante. $\mathrm{O}$ artigo 72 da Lei de Licitações estabelece o seguinte:

Art. 72. O contratado, na execução do contrato, sem prejuízo das responsabilidades contratuais e legais, poderá subcontratar partes da obra, serviço ou fornecimento, até o limite admitido, em cada caso, pela Administração ${ }^{43}$.

A subcontratação só poderá ser efetuada quando houver previsão no edital da licitação. Se não houver tal previsão e a subcontratação for efetuada, haverá motivo para ocorrer a rescisão contratual, segundo o artigo 78 , inciso VI, da Lei de Licitações:

Art. 78. Constituem motivo para rescisão do contrato:

VI - a subcontratação total ou parcial do seu objeto, a associação do contratado com outrem, a cessão ou transferência, total ou parcial, bem como a fusão, cisão ou incorporação, não admitidas no edital e no contrato ${ }^{44}$.

O pagamento direto à subcontratada, permite maior controle sobre o andamento das atividades objeto da subcontratação. E não cria uma relação jurídica entre contratante e subcontratada, como à primeira vista - e erroneamente - se poderia supor ${ }^{45}$. Ou seja, a subcontratada não se torna contratada principal. Ela é uma representante da contratada principal, para o fim específico de receber parcela do preço devido pela contratante ${ }^{46}$.

No entanto, há alguns autores que argumentam que na ocorrência do faturamento direto em que a contratante paga diretamente à contratada, há o

\footnotetext{
${ }^{43}$ Lei n. 8.666, de 21 de junho de 1993. Lei de Licitações. Artigo 72.

${ }_{45}^{44}$ Lei n. 8.666, de 21 de junho de 1993. Lei de Licitações. Artigo 78.

${ }^{45}$ AMARAL, Antônio Carlos Cintra do. Anulação de contrato já cumprido. Alteração do método construtivo e alteração do objeto contratual. Faturamento direto à contratante, efetuado por subcontratada. Revista Brasileira de Infraestrutura - RBINF. Belo Horizonte: Editora Fórum, 2012. p. 151.

${ }^{46}$ AMARAL, Antônio Carlos Cintra do. Anulação de contrato já cumprido. Alteração do método construtivo e alteração do objeto contratual. Faturamento direto à contratante, efetuado por subcontratada. Revista Brasileira de Infraestrutura - RBINF. Belo Horizonte: Editora Fórum, 2012. p. 152-153.
} 
escape do pagamento de Imposto sobre Serviços de Qualquer Natureza (“ISS"). Antônio Carlos Cintra do Amaral apresenta a seguinte hipótese para explicar o motivo pelo qual não concorda que o faturamento direto não consiste em fuga à tributação:

\begin{abstract}
"Se a contratante deve à contratada principal uma determinada quantia, por exemplo 100 , e esta subcontrata parcela dos serviços, por exemplo 20 , e se a contratante paga 100 à contratada principal, e esta paga 20 à subcontratada, o ISS incide sobre 120 . Esta, porém, não é a receita real gerada pela execução dos serviços contratados. A receita real corresponde à despesa da contratante, ou seja, 100. Assim, a tributação do ISS incide, nesse exemplo, sobre um valor $20 \%$ maior do que a receita real gerada pela execução dos serviços contratados.
\end{abstract}

Se a contratante paga 80 à contratada principal e 20 à subcontratada, mediante indicação por ela efetuada, o ISS incidirá sobre 100, que corresponde à receita real gerada pela execução dos serviços contratados. Diante desta demonstração, não se pode dizer que a indicação da subcontratada para receber diretamente da contratante a importância correspondente ao pagamento dos serviços objeto da subcontratação constitua fuga à tributação. Pelo contrário: trata-se de fazer incidir o ISS sobre a receita federal, ou seja, trata-se de ajustar a tributação à realidade econômica contratual, englobados os dois contratos, o principal e o derivado" ${ }^{, 47}$.

Além de ser possível a subcontratação e faturamento direto no contrato de empreitada, também é juridicamente admissível que a subcontratação nos Contratos EPC, tendo em vista que a Cláusula 4.4 do FIDIC estabelece o seguinte:

“4.4 - Subempreiteiros:

O Empreiteiro não pode subcontratar a totalidade dos Trabalhos:

O Empreiteiro é responsável pelos atos e descumprimentos de qualquer Subempreiteiro, seus representantes ou empregados, tal como se fossem atos ou descumprimentos do Empreiteiro. Quando previsto nas Condições Particulares, o Empreiteiro notificará o Dono da Obra com a antecedência mínima de 28 dias:

(a) da intenção de contratar o Subempreiteiro, com informação detalhada que incluirá a respectiva experiência de relevo;

(b) a data prevista de início dos trabalhos do Subempreiteiro; e

\footnotetext{
47 AMARAL, Antônio Carlos Cintra do. Anulação de contrato já cumprido. Alteração do método construtivo e alteração do objeto contratual. Faturamento direto à contratante, efetuado por subcontratada. Revista Brasileira de Infraestrutura - RBINF. Belo Horizonte: Editora Fórum, 2012. p. 153.
} 
(c) a data prevista de início dos trabalhos do Subempreiteiro no Local da Obra" $"$.

O faturamento direto é permitido nos Contratos EPC em que a contratante paga diretamente à subcontratada ocorrendo a diminuição da carta tributária da operação. Contudo, os contratos estipulam um valor mínimo para cada fatura. Se esse valor mínimo não for atingido, o faturamento não pode ser feito pelos subcontratados ao dono da obra. No entanto, o faturamento direto não isenta o "Epcista" de suas responsabilidades e, portanto, continua sendo único e exclusivamente responsável pelo total desempenho das obrigações dos subcontratados.

Sendo assim, devido à responsabilidade integralmente assumida pelo "Epcista" perante o dono da obra para a execução satisfatória do escopo e demais obrigações dos subcontratados, no caso de ato ou omissão e violação das obrigações que causem perda ou dano ao dono da obra, o "Epcista" indenizará o dono da obra, além de suportar todas as consequências de tal inadimplemento, perda ou dano.

\subsection{Formação de Preço Pago ao "Epcista"}

A compreensão do processo de formulação de preço pago ao "Epcista" é importante e relevante no julgamento dos pleitos de reequilíbrio econômicofinanceiro do Contrato EPC e da alocação contratual de riscos.

Nos contratos EPC há três formas de regime de preços: preço global, preço por administração e preço por unidade de medida.

O preço global é aquele cujo valor é pré-definido pelas partes mesmo que haja modificações dos custos suportados pela contratada necessários à

\footnotetext{
48 FIDIC Condições Contratuais para Projetos Chave na Mão. Condições gerais, guia para a preparação das condições particulares, minutas da carta-proposta, acordo contratual e acordo de resolução de conflitos. Genebra, FIDIC, 1. ed.. 1999. p 13.
} 
execução do empreendimento. A FIDIC contém cláusula que exemplifica o modelo de preço global:

\section{“4.11 Suficiência do Preço Contratual}

Considera-se que o Empreiteiro se certificou da correção e suficiência do Preço Contratual.

Salvo disposição em contrário no Contrato, o Preço Contratual cobre todas as obrigações do empreiteiro previstas no Contrato (incluindo as previstas nos Montantes Provisórios) e tudo o que for necessário para o projeto, a execução e conclusão dos Trabalhos e a reparação de quaisquer defeitos"

Já o preço por administração sofre variações devido às mudanças dos custos de materiais e serviços para a execução das obras. Sua configuração básica é identificada segundo dois elementos: a variação do custo dos insumos utilizados e uma "taxa de administração" (fee), usualmente estabelecida como um percentual dos custos efetivos ${ }^{50}$.

O preço por unidade de medida pode ser entendido como uma fusão dos modelos de preço apresentados acima. Nessa modalidade, o preço é calculado por unidade de medida como o próprio nome já indica, por exemplo, estabelece-se um preço específico para o metro cúbico de cimento. O preço de cada unidade é multiplicado pela quantidade que foi executada. Também é possível contratar um serviço específico com base em uma tarifa cobrada por hora trabalhada.

É difícil saber qual regime de preço é mais benéfico ao dono da obra pois a oscilação dos custos efetivos estão presente em todos os regimes. Apesar dessa flutuação dos custos ser clara no regime de preço por administração, o contrato por regime de preço global também está sujeito à variação dos custos, dado que o preço global é geralmente complementado por

\footnotetext{
49 FIDIC Condições Contratuais para Projetos Chave na Mão. Condições gerais, guia para a preparação das condições particulares, minutas da carta-proposta, acordo contratual e acordo de resolução de conflitos. Genebra, FIDIC, 1. ed.. 1999. p 15.

${ }^{50}$ GIL, Fabio Coutinho de Alcântara. A Onerosidade Excessiva em Contratos de Engineering. São Paulo. 2007. 143. Tese (Doutorado). Universidade de São Paulo. p. 81.
} 
um sobrevalor (na prática empresarial, designado, sem grande precisão terminológica, contingência, provisão ou margem) correspondente a uma avaliação da probabilidade de variação futura e do montante que essa variação atingiria $^{51}$.

O regime do preço global pode ser visto como o melhor dos regimes, uma vez que oferece à contratante uma espécie de seguro, visto que as premissas inicialmente contratadas (premissas que não sejam controladas pela contratada) não sejam modificadas gerando o desequilíbrio contratual.

\begin{abstract}
"Ambas as partes no contrato estarão sujeitas a vicissitudes e comportamentos oportunistas. O contrato a preço global, à semelhança do contrato de compra e venda, embute conflito de interesses entre o empreiteiro, que deseja "vender" a obra com o maior lucro possível, e o dono da obra, em posição contrária, desejando pagar o menor preço possível. À diferença de compra e venda instantânea, no entanto, o contrato é de longa duração e abre-se a possibilidade de surgimento de contingências, decorrentes de comportamentos oportunistas, ou não" ${ }^{\text {"52 }}$.
\end{abstract}

Para fins de futura análise do reequilibro econômico-financeiro do Contrato EPC, consideraremos o regime de preço global no qual ocorre a variação implícita dos custos necessários à execução do empreendimento.

O "Epcista" só consegue começar a formular o preço global após o recebimento, pelo dono da obra, do projeto básico de engenharia e os estudos preliminares relativos à execução do empreendimento. Geralmente, há a contratação de mais de uma empresa de engenharia para produzir os estudos preliminares, além do projeto básico e é uma dessas empresas que normalmente também supervisionará o "Epcista" durante os trabalhos. Essa empresa é chamada de empresa de engenharia de proprietário (owner's engineer). Sendo assim, como base nessas informações, o "Epcista" conseguirá formular o seu preço.

\footnotetext{
${ }^{51}$ GIL, Fabio Coutinho de Alcântara. A Onerosidade Excessiva em Contratos de Engineering. São Paulo. 2007. 143. Tese (Doutorado). Universidade de São Paulo. p. 82.

${ }^{52}$ GIL, Fabio Coutinho de Alcântara. A Onerosidade Excessiva em Contratos de Engineering. São Paulo. 2007. 143. Tese (Doutorado). Universidade de São Paulo. p. 87.
} 
É pressuposto que, para a formulação de preço global, na modalidade EPC, uma grande quantidade de informações esteja disponível ${ }^{53}$. Quanto maior for o número de informações fornecida pelo "Epcista", maior será a segurança do dono da obra, e, portanto, menor deveria ser o preço formulado.

\begin{abstract}
"O preço ofertado pelo epcista será definido não só em função do escopo técnico da obra, mas também em função do grau de precisão da engenharia e ele relacionada, pelos requisitos da qualidade, pelo regime tributário incidente, pelas condições de acesso ao local, pelas condições climáticas das obras, pelas condições geotécnicas, geológicas e hidrológicas (conforme o tipo de obra), pelas condicionantes ambientais existentes em licenças ambientais do empreendimento, pelas normas internas da contratante, pela estrutura existente no local das obras, dentre muitos outros. O que se pretende demonstrar, em poucas palavras, é que o preço formulado pelo epcista é, basicamente, o resultado da aceitação de uma série de premissas técnicas, comerciais e até jurídicas. ${ }^{, 54}$.
\end{abstract}

O "Epcista" só consegue formular seu preço após verificar as diversas premissas já, tendo em vista que se no decorrer da execução do empreendimento, o "Epcista" descobrir que uma das premissas apresentadas pelo dono da obra era incorreta, imprecisa ou incompleta, terá um custo adicional inicialmente não previsto.

Apesar do dono da obra apresentar a maioria das premissas, ele não necessariamente será responsável pela incompletude, incorreção e imprecisão das premissas disponibilizadas ao "Epcista". A responsabilização pela apresentação de premissas falsas depende do que for negociado e estabelecido no próprio Contrato EPC. Alguns modelos de Contratos EPC internacionais, passíveis de sofrer adaptações que variam de acordo com os casos contratados, estabelecem, como é o modelo EPC publicado pela FIDIC (Silver Book), a

53 SILVA, Leonardo Toledo da. Direito e Infraestrutura. Disponível em: < https://books.google.com.br/books?isbn=8502130749>. Acesso em 29 de setembro de 2018.

54 SILVA, Leonardo Toledo da. Direito e Infraestrutura. Disponível em: < https://books.google.com.br/books?isbn=8502130749>. Acesso em 29 de setembro de 2018. 
obrigação do "Epcista" de checar e validar os projetos apresentados pelo dono da obra ${ }^{55}$.

É de extrema importância que as partes respeitem a alocação de riscos negociadas entre contratante e contratada, principalmente em contratos de execução de obras de grande porte. Essa também pode ser vista como uma das principais estruturas dos Contratos EPC e dos contratos de construção de complexas obras de engenharia em que as partes identificam os principais riscos do projeto, divindo-os entre si e já preestabelecendo soluções específicas sobre como lidar com esses riscos, independentemente de quem os $\operatorname{assumir}^{56}$.

A contratada contingencia no preço formulado à contratante os riscos que pretende assumir no intuito de ter verba suficiente para lidar com eventuais adversidades no decorrer do projeto. No entanto, há eventos imprevisíveis, daí a possibilidade de se realizarem pleitos de recomposição de seu preço nos termos da teoria da imprevisão, ainda que em relação a riscos a ele alocados ${ }^{57}$. Todavia, a contingencia somente poderá ser feita baseada em riscos que são possíveis de previsão.

A possibilidade de redistribuição de eventuais prejuízos sofridos pela construtora com os demais contratos celebrados por ela, só será possível em contratos de massa, como, por exemplo, os contratos de consumo. Nesse tipo de contrato, um eventual desequilíbrio desfavorável ao fornecedor não é objeto de revisão do contrato, o qual, na prática, acaba sendo subsidiado pelos demais $^{58}$.

\footnotetext{
55 SILVA, Leonardo Toledo da. Direito e Infraestrutura. Disponível em: < https://books.google.com.br/books?isbn=8502130749>. Acesso em 29 de setembro de 2018.

56 SILVA, Leonardo Toledo da. Direito e Infraestrutura. Disponível em: < https://books.google.com.br/books?isbn=8502130749>. Acesso em 08 de novembro de 2018.

57 SILVA, Leonardo Toledo da. Direito e Infraestrutura. Disponível em: < ${ }_{58}$ ttps://books.google.com.br/books?isbn=8502130749>. Acesso em 29 de setembro de 2018.

58 SILVA, Leonardo Toledo da. Direito e Infraestrutura. Disponível em: < https://books.google.com.br/books?isbn=8502130749>. Acesso em 29 de setembro de 2018.
} 
Todavia, nos contratos de execução de obras de infraestrutura de grande porte em que cada contrato possui peculiaridades específicas relacionadas ao escopo contratado, ou seja, contratos bilionários que não se repetem em escala, impedindo um sistema de redistribuição de prejuízo ocorrido em uma determinada obra ${ }^{59}$.

Além do mais, conforme entendimento de Leonardo Toledo da Silva é importante ressaltar que a formulação do prazo para a entrega do projeto completo é uma premissa tão importante quanto à formulação de preço. Dessa forma, o pleito para extensão de prazo das obras virá acompanhado pelo pleito de aumento de preço pois eventual modificação do prazo gera impactos nos custos de execução dos projetos.

A prorrogação de prazo decorrente de eventos de força maior é tratada em conformidade com o princípio Back-to-Back nos Contratos EPC. Os Contratos EPCs contém cláusulas que estabelecem que se o evento de força maior persistir por mais de 10 meses, impedindo a contratante de realizar suas obrigações, então a contratante pode, a seu critério: (i) rescindir o contrato; ou (ii) suspender o contrato.

Já a prorrogação de prazo das datas de conclusão a pedido da contratante só pode ser concedida em razão de hipóteses previamente pactuados no EPC.

Ainda, as multas são devidas e pagas quando os marcos fixos dos trabalhos não são concluídos nas datas pactuadas ou na data de conclusão. Além das multas devidas, a contratada precisa apresentar à contratante, dentro do período de tempo estabelecido (geralmente 10 dias), relatório indicado as razões de atraso e plano de recuperação para recuperar o atraso e concluir os marcos subsequentes de acordo com o cronograma. Além disso, a multa é geralmente limitada à $20 \%$ do preço contratual.

59 SILVA, Leonardo Toledo da. Direito e Infraestrutura. Disponível em: < https://books.google.com.br/books?isbn=8502130749>. Acesso em 08 de novembro de 2018. 


\section{Capítulo 4: Onerosidade Excessiva 4.1. A Relativização da Força Obrigatória do Contrato}

O contrato cria obrigações bilaterais ou multilaterais. Tais obrigações nascem do princípio da autonomia da vontade das partes contratantes, ou seja, confere-se às partes a mais ampla liberdade de disciplinarem seus interesses através da celebração de um instrumento contratual. Uma das expressões deste princípio é a possibilidade de celebrar contratos não previstos em lei, comumente conhecidas como contratos atípicos. A obrigação pactuada é adimplida pelas partes o mais rápido possível com o intuito de aperfeiçoar o negócio jurídico celebrado. Neste sentido, podemos dizer que a obrigação nasce para ser cumprida, seja imediatamente ou em um interregno de tempo que, invariavelmente, tende para zero, na medida em que este é o seu caminho natural ${ }^{60}$. Conforme aponta Sílvio de Salvo Venosa:

"As obrigações surgem para ter existência mais ou menos efêmera, transitória, fugaz. Uma vez cumpridas, exaurem seu papel no campo social, propiciando a circulação de riquezas, a criação de obras, a realização, por que não dizer, de sonhos e ideais" ${ }^{\prime \prime 1}$.

O adimplemento da obrigação significa a extinção do contrato. A intenção das partes contratantes é a extinção do contrato pelo meio natural do adimplemento. Para que essa intenção seja observada e seguida pelas partes há a aplicação do princípio da força obrigatória dos contratos, ou, pacta sunt servanda. De um certo modo, esse princípio decorre do princípio da autonomia da vontade em que as partes são livres para contratar e cumprir as obrigações contratadas, observados os limites da lei e os requisitos de validade do negócio jurídico.

\footnotetext{
${ }^{60}$ FOUNTOURA, Rodrigo Brandão. Onerosidade Excessiva nos Contratos de Comercialização de Energia Elétrica. VIVAN, Alexei Macorin; SILVEIRA, Rodrigo Maito da. Direito e energia. São Paulo: Quartier Latin, 2014. p. 179.

${ }^{61}$ VENOSA, Sílvio de Salvo. Direito Civil: Teoria Geral das Obrigações e Teoria Geral dos Contratos. 14a ed.. São Paulo: Atlas, 2014. p. 291.
} 
Resta evidente a importância deste princípio que gera o exercício da segurança jurídica em que as partes têm ciência que estão vinculadas às obrigações assumidas. O princípio da força obrigatória dos contratos sofreu relativizações.

\begin{abstract}
"Isso fica claro ao abordarmos temas como a possibilidade de resolução por inexecução contratual, onde a quebra das condições pactuadas resulta no direito ao seu rompimento; a resilição unilateral, onde a própria lei, em situações específicas, permite a ruptura do pacto; as hipóteses de desequilíbrio contratual ligado ao atendimento da boa-fé objetiva e da função social do contrato; e as hipóteses de revisão contratual fundamentadas no princípio do rebus sic stantibus, que permite a revisão judicial das condições da avença ou a resolução por onerosidade excessiva",62.
\end{abstract}

Se busca o restabelecer o equilíbrio contratual entre as partes, rompido por fatos supervenientes imprevisíveis gerando a onerosidade excessiva. A mudança das condições inicialmente contratadas implica a revisão ou extinção do contrato. Essa é a base do princípio da revisão contratual e o fundamento da teoria da imprevisão, baseados no artigo 317 do Código Civil ${ }^{63}$.

Há uma série de hipóteses de revisão contratual, como, por exemplo, o desequilíbrio contratual, ofensa à boa-fé objetiva, quebra da base objetiva do negócio e desproporção da prestação, etc. No entanto, apesar da autorização da revisão contratual, a tendência dos usos e costumes e do judiciário é somente relativizar o pacta sunt servanda no caso das possibilidades de revisão contratual estarem bem demonstradas e demandarem a aplicação do rebus sic stantibus. A onerosidade excessiva é um exemplo clássico da ocorrência dessa relativização quando há a presença de uma série de condições e requisitos.

\footnotetext{
${ }^{62}$ FOUNTOURA, Rodrigo Brandão. Onerosidade Excessiva nos Contratos de Comercialização de Energia Elétrica. VIVAN, Alexei Macorin; SILVEIRA, Rodrigo Maito da. Direito e energia. São Paulo: Quartier Latin, 2014. p. 180.

${ }^{63}$ FOUNTOURA, Rodrigo Brandão. Onerosidade Excessiva nos Contratos de Comercialização de Energia Elétrica. VIVAN, Alexei Macorin; SILVEIRA, Rodrigo Maito da. Direito e energia. São Paulo: Quartier Latin, 2014. p. 180.
} 


\subsection{Teoria da Onerosidade Excessiva}

Primeiramente, é importante ressaltar que não é possível pedir a revisão do instrumento contratual com base na onerosidade excessiva. Tal fato é explícito no artigo 478 do Código Civil, que estabelece a resolução do contrato em virtude da onerosidade excessiva. A revisão do contrato com a modificação de sua desproporcionalidade é vista como um "plano b" prevista no artigo 479 do mesmo diploma legal.

"Art. 478. Nos contratos de execução continuada ou diferida, se a prestação de uma
das partes se tornar excessivamente onerosa, com extrema vantagem para a outra, em
virtude de acontecimentos extraordinários e imprevisíveis, poderá o devedor pedir a
resolução do contrato. Os efeitos da sentença que a decretar retroagirão à data da
citação" 64 . “Art. 479. A resolução poderá ser evitada, oferecendo-se o réu a modificar eqüitativamente as condições do contrato" $"$.

É claro que, exatamente por coexistirem na lei de forma subsequencial, a revisão do contrato acaba por se tornar o deslinde natural do pedido de resolução por onerosidade excessiva, até em função do princípio da preservação dos $\operatorname{contratos}^{66}$. Muitas vezes entende-se que o pedido de resolução por onerosidade excessiva é na verdade o pedido de revisão do contrato. Todavia, o instituto da onerosidade excessiva não é um "abre alas" para pleitos de modificação das cláusulas originalmente pactuadas resultantes de fatos supervenientes.

Conforme exposto acima, a caracterização da onerosidade excessiva resultante na revisão contratual depende do reconhecimento de várias condições e requisitos. Ao analisar os detalhes do artigo 478 do Código Civil é

\footnotetext{
${ }^{64}$ Lei n. 10.406, de 10 de janeiro de 2002. Código Civil. Artigo 478.

${ }^{65}$ Lei n. 10.406, de 10 de janeiro de 2002. Código Civil. Artigo 479.

${ }^{66}$ FOUNTOURA, Rodrigo Brandão. Onerosidade Excessiva nos Contratos de Comercialização de Energia Elétrica. VIVAN, Alexei Macorin; SILVEIRA, Rodrigo Maito da. Direito e energia. São Paulo: Quartier Latin, 2014. p. 182.
} 
possível verificar quais são os requisitos necessários. Caio Mário dispõe sobre os requisitos:

"Para que se possa invocar a resolução por onerosidade excessiva é necessário que ocorram requisitos de apuração certa, explicitados no Código Civil: a) vigência de um contrato de execução diferida ou sucessiva; b) alteração radical das condições econômicas objetivas no momento da execução, em confronto com o ambiente objetivo no da celebração; c) onerosidade excessiva para um dos contratantes e benefício exagerado para o outro; d) imprevisibilidade daquela modificação"67.

Faz-se necessário analisar o artigo 418 que adota a teoria da imprevisão e dispõe que "em virtude de acontecimentos extraordinários e imprevisíveis" verifica-se a onerosidade excessiva. Qualquer acontecimento que fuja da condição originalmente contratada e que não possa ser prevista motivará a revisão do contrato por onerosidade excessiva. Por esta linha de raciocínio, não se condiciona o pleito à imprevisibilidade dos fatos, que podem até ser previsíveis, mas sim aos fatos que tornam a prestação excessivamente onerosa $^{68}$.

\subsection{Legislação}

A jurisprudência brasileira permite a resolução e a revisão contratual por onerosidade excessiva. A relativização do pacta sunt servanda devido à onerosidade excessiva ocorre nos contratos celebrados à luz do Código Civil, da Lei n. 8.078, de 11 de setembro de 1990 ("Código de Defesa do Consumidor" ou "CDC") e também com base na Lei de Licitações, além de encontrar reflexos em normas específicas de contratos em espécie.

\footnotetext{
${ }^{67}$ PEREIRA, Caio Mário da Silva de. Instituições de Direito Civil, volume III: Contratos. 13 ed. Rio de Janeiro: Forense, 2009. p. 166.

${ }^{68}$ FOUNTOURA, Rodrigo Brandão. Onerosidade Excessiva nos Contratos de Comercialização de Energia Elétrica. VIVAN, Alexei Macorin; SILVEIRA, Rodrigo Maito da. Direito e energia. São Paulo: Quartier Latin, 2014. p. 185.
} 
A onerosidade excessiva no Código de Defesa do Consumidor possui tratamento diferenciado visto que o direito do consumidor conta com princípios próprios e disposições especiais aplicáveis às relações de consumo ${ }^{69}$ e que visam proteger o consumidor. A proteção ao consumidor é vista em todas as decisões jurisprudenciais que dispõem sobre a onerosidade excessiva, no entanto, o tema de onerosidade excessiva é tratado com grande imprecisão nas relações de consumo. A jurisprudência faz uso da onerosidade excessiva para designar situação na qual o consumidor se encontra em uma posição gravosa quando comparada à outra parte.

A configuração de situação demasiadamente gravosa para uma das partes, contudo, não advém necessariamente da ocorrência de um fato superveniente à formação do contrato, nos termos do artigo 6 , inciso $\mathrm{V}$, do $\mathrm{CDC}^{70}$.

“Art. $6^{\circ}$. São direitos básicos do consumidor:

$\mathrm{V}$ - a modificação das cláusulas contratuais que estabeleçam prestações desproporcionais ou sua revisão em razão de fatos supervenientes que as tornem excessivamente onerosas" ${ }^{\prime 71}$.

A onerosidade excessiva pode ser configurada na formação do contrato. Além disso, o artigo 39, inciso $\mathrm{V}$, do CDC veda que o fornecedor exiga do consumidor vantagem manifestamente excessiva.

“Art. 39. É vedado ao fornecedor de produtos ou serviços, dentre outras práticas abusivas:

$\mathrm{V}$ - exigir do consumidor vantagem manifestamente excessiva"72.

${ }^{69}$ GIL, Fabio Coutinho de Alcântara. A Onerosidade Excessiva em Contratos de Engineering. São Paulo, 2007. 146. Tese (Doutorado). Universidade de São Paulo. p. 94.

${ }^{70}$ GIL, Fabio Coutinho de Alcântara. A Onerosidade Excessiva em Contratos de Engineering. São Paulo, 2007. 146. Tese (Doutorado). Universidade de São Paulo. p. 95.

${ }^{71}$ Lei n. 8.078, de 11 de setembro de 1990. Código de Defesa do Consumidor. Artigo $6^{\circ}$.

${ }^{72}$ Lei n. 8.078, de 11 de setembro de 1990. Código de Defesa do Consumidor. Artigo 39. 
Caso se verifique a exigência de vantagem manifestamente excessiva, ou seja, a configuração da onerosidade excessiva, a revisão ou resolução do contrato é justificada.

Analisaremos o Código Civil e a Lei de Licitações para saber qual o conteúdo das normas que são aplicáveis aos contratos de empreitada com a intenção de recompor o seu equilíbrio econômico-financeiro. Tendo em vista que as normas do Código de Defesa do Consumidor tutelam um escopo diferente do que será tratado adiante, tais normas não são aplicáveis aos Contratos EPC.

O Código Civil trouxe dispositivos que permitem a revisão do contrato, dado que abarcam a teoria da imprevisão. Os artigos 317 e 478, preveem a revisão contratual diante de eventos imprevisíveis.

“Art. 317. Quando, por motivos imprevisíveis, sobrevier desproporção manifesta entre o valor da prestação devida e o do momento de sua execução, poderá o juiz corrigi-lo, a pedido da parte, de modo que assegure, quanto possível, o valor real da prestação"

Isso significa que a prestação a ser cumprida contratualmente poderá ser corrigida, se, no momento de sua execução, motivos imprevisíveis tiverem causado desproporção manifesta no valor da prestação devida quando comparada ao momento de celebração contratual.

O artigo 317 contém requisitos necessários para que seja aplicada a teoria da imprevisão, quais sejam: (i) ocorrência de motivos imprevisíveis; (ii) existência de desproporção manifesta entre o valor da prestação devida entre o do momento de sua execução; e (iii) lapso temporal entre a celebração e execução do contrato. Se os requisitos mencionados forem verificados, o referido artigo dispõe que o juiz poderá intervir na relação jurídica estabelecida entre as partes para corrigir e adequar o valor da prestação devida.

\footnotetext{
${ }^{73}$ Lei n. 10.406, de 10 de janeiro de 2002. Código Civil. Artigo 317.
} 
Muitos entendem a possibilidade de intervenção do juiz como uma violação ao princípio da autonomia da vontade. Já o artigo 478 estabelece que:

“Art. 478. Nos contratos de execução continuada ou diferida, se a prestação de uma das partes se tornar excessivamente onerosa, com extrema vantagem para a outra, em virtude de acontecimentos extraordinários e imprevisíveis, poderá o devedor pedir a resolução do contrato. Os efeitos da sentença que a decretar retroagirão à data da citação" ${ }^{, 74}$.

Esse artigo traz os seguintes requisitos para que ocorra a resolução do contrato quando uma das partes for prejudicada por acontecimentos extraordinários e imprevisíveis: (i) existência de contrato de execução diferida ao longo do tempo; (ii) ocorrência de fatos extraordinários e imprevisíveis; e (iii) tais fatos resultem na onerosidade excessiva com vantagem à uma das partes contratantes. Diferentemente do artigo 318, que permite a revisão contratual pela intervenção do juiz, o artigo 478 possibilita a resolução do contrato.

Dessa forma, é possível notar diferenças existentes entre os artigos. A primeira diz respeito ao artigo 317 que determina a "desproporção manifesta entre o valor da prestação devida e do momento de sua execução" enquanto o artigo 478 dá ênfase a onerosidade excessiva em que a "prestação de uma das partes se tornar excessivamente onerosa com extrema vantagem para a outra". A segunda diferença refere-se às soluções apresentadas, já que o artigo 317 permite a revisão contratual enquanto o artigo 478 permite a resolução contratual.

A resolução do contrato pode ser evitada se o réu modificar equitativamente as condições do contrato, conforme dispõe o artigo 479 do Código Civil. Se o juiz entender que a modificação apresentada pelo réu gera o equilíbrio contratual, o pedido de resolução se torna improcedente.

\footnotetext{
${ }^{74}$ Lei n. 10.406, de 10 de janeiro de 2002. Código Civil. Artigo 478.
} 
"No entanto, embora os poderes conferidos ao juiz pelo artigo 479 sejam mais amplos diante do oferecimento da proposta pelo réu (pois o magistrado poderá alterar todas as condições de proposta que, a seu juízo, não pareçam equitativas, inclusive as que digam respeito à alocação dos riscos) em relação ao artigo 317 , seus poderes são, de um lado, mais incisivos, e, de outro, menos amplos. Mais incisivos porque, caso o autor da ação fundamente o pedido de revisão com base no artigo 317 , o juiz poderia rever o valor da prestação ainda que o réu não se dispusesse a oferecer a proposta modificativa do contrato. Por outro lado, esses poderes seriam menos amplos que os conferidos pelo artigo 479, pois, aplicando o artigo 317 , ao juiz caberia apenas rever o valor da prestação ainda que o réu não se dispusesse a oferecer a proposta modificativa do contrato. Por outro lado, esses poderes seriam menos amplos que os conferidos pelo artigo 479, pois, aplicando o artigo 317, ao juiz caberia apenas rever o valor da prestação - e não a alocação global de riscos do contrato" $" 75$.

Nos contratos administrativos, a configuração da onerosidade excessiva é vista dentro do tema do equilíbrio econômico-financeiro contratual. $\mathrm{O}$ equilíbrio do contrato pode ser entendido como a relação originária entre encargos do particular e a contraprestação assegurada pela Administração ${ }^{76}$.

É de extrema importância analisar a Lei de Licitações que estabelece as regras aplicadas aos contratos administrativos. Mesmo que tal lei somente tenha aplicação aos contratos celebrados com a Administração Pública, suas normas podem ser usadas para interpretar conflitos decorrentes dos contratos de construção, em especial, os contratos EPC.

$\mathrm{O}$ artigo 65 , II, $d$, da Lei de Licitações abrange a teoria da imprevisão estabelecendo que:

“Art. 65. Os contratos regidos por esta lei poderão ser alterados, com as devidas justificativas, nos seguintes casos:

II - por acordo das partes:

d) para restabelecer a relação que as partes pactuaram inicialmente entre os encargos do contratado e a retribuição da administração para a justa remuneração da obra, serviço ou fornecimento, objetivando a manutenção do equilíbrio econômicofinanceiro inicial do contrato, na hipótese que sobrevierem fatos imprevisíveis, ou

\footnotetext{
75 GIL, Fabio Coutinho de Alcântara. A Onerosidade Excessiva em Contratos de Engineering. São Paulo. 2007. 146. Tese (Doutorado). Universidade de São Paulo. p. 79.

${ }^{76}$ GIL, Fabio Coutinho de Alcântara. A Onerosidade Excessiva em Contratos de Engineering. São Paulo, 2007. 146. Tese (Doutorado). Universidade de São Paulo. p. 103.
} 
previsíveis porém de consequências incalculáveis, retardadores ou impeditivos da execução do ajustado, ou, ainda, em caso de força maior, caso fortuito ou fato do príncipe, configurando área econômica extraordinária e contratual”,77.

O artigo mostra que há a possibilidade de revisão contratual no caso de eventos imprevisíveis ou até mesmo de eventos previsíveis que tenham consequências incalculáveis, como, por exemplo, crise financeira que venha assolar o país. O mesmo dispositivo ainda menciona outras hipóteses dogmáticas que justificam a revisão do pacto original, quais sejam as hipóteses de força maior, caso fortuito ou fato do príncipe ${ }^{78}$.

O equilíbrio econômico-financeiro do contrato, ou seja, a relação original entre encargos do particular e a contraprestação assegurada pela Administração $^{79}$ é de suma importância na Lei de Licitações, dado que é protegido pela Constituição Federal em seu artigo 37, XXI.

O artigo 57 da Lei de Licitações também abarca a teoria da imprevisão, permitindo a modificação contratual quando há a ocorrência de fato excepcional ou imprevisível, estranho à vontade das partes, que altere as condições contratadas, conforme se demonstra:

“Art. 57. A duração dos contratos regidos por esta Lei ficará adstrita à vigência dos respectivos créditos orçamentários, exceto quanto aos relativos:

$\S 1^{\circ}$ Os prazos de início de etapas de execução, de conclusão e de entrega admitem prorrogação, mantidas as demais cláusulas do contrato e assegurada a manutenção de seu equilíbrio econômico-financeiro, desde que ocorra algum dos seguintes motivos, devidamente autuados em processo:

II - superveniência de fato excepcional ou imprevisível, estranho à vontade das partes, que altere fundamentalmente as condições de execução do contrato" ${ }^{~} 80$.

\footnotetext{
${ }_{77}^{77}$ Lei n. 8.666, de 21 de junho de 1993. Lei de Licitações. Artigo 65, II, $b$.

78 SILVA, Leonardo Toledo da. Direito e Infraestrutura. Disponível em: < https://books.google.com.br/books?isbn=8502130749>. Acesso em 08 de novembro de 2018.

79 SILVA, Leonardo Toledo da. Direito e Infraestrutura. Disponível em: < https://books.google.com.br/books?isbn=8502130749>. Acesso em 29 de setembro de 2018 .

${ }^{80}$ Lei n. 8.666, de 21 de junho de 1993. Lei de Licitações. Artigo 57, §1, II.
} 
Após a análise do Código Civil e da Lei de Licitações, é possível perceber que o legislador não se preocupou em definir de forma precisa e taxativa os requisitos que ensejam a revisão do contrato.

\begin{abstract}
"Os traços comuns que parecem se repetir, nos dispositivos analisados, ainda que com nomenclaturas variadas e ênfase maior a um ou outro requisito, são: i) ocorrência de fato superveniente imprevisível; e ii) o desequilíbrio entre as prestações contratuais pactuadas" ${ }^{, 1}$.
\end{abstract}

\title{
4.4. Jurisprudência dos Tribunais Brasileiros
}

Frente a isso, os julgados abaixo expostos, analisam o tema do reequilíbrio econômico-financeiro contratual. A Quinta Câmara Cível do Tribunal de Justiça do Estado do Paraná, nos autos da Apelação Cível $n^{\circ}$ 907.096-2, por exemplo, reconheceu que ocorre o reequilíbrio econômicofinanceiro nos contratos administrativos na hipótese em que houver um fato extraordinário, seja alheio aos contratantes, seja um factum príncipes, imprevisível, que onere sobremaneira o particular no cumprimento das obrigações $^{82}$. Tal concepção, contida na teoria da imprevisão, conforme já visto, está positivada no artigo 65 , inciso II, $d$, da Lei de Licitações.

“1) DIREITO ADMINISTRATIVO. CONTRATOS ADMINISTRATIVOS. ART. 65, II, d, DA LEI No 8.666/93. ÁLEA EXTRAORDINÁRIA. REEQUILÍBRIO ECONÔMICO-FINANCIERO. NÃO SE CONFUNDE COM A DIMINUIÇÃO DA LUCRATIVIDADE DO CONTRATO AO LONGO DOS ANOS. Para a caracterização do desequilíbrio econômico-financeiro do contrato administrativo é imprescindível a demonstração de álea extraordinária, vale dizer, fatos imprevisíveis, ou previsíveis porém de consequências incalculáveis, retardadores ou impeditivos da execução do ajustado, ou, ainda, em caso de força maior, caso fortuito ou "factum princeps. No caso, a particular renovou, com autonomia privada, o contrato administrativo durante vários anos, tendo garantida apenas a correção monetária do valor em razão da inflação. Com o tempo, o preço de custeio do serviço aumentou, diminuindo a lucratividade. Isso, no entanto, não caracteriza o desequilíbrio

\footnotetext{
${ }^{81}$ SILVA, Leonardo Toledo da. Direito e Infraestrutura. Disponível em: < https://books.google.com.br/books?isbn=8502130749>. Acesso em 09 de outubro de 2018.

82 TJPR, Apelação Cível n. 907.096-2, Rel. Desembargador Leonel Cunha, Paraná, 06 de novembro de 2012 .
} 
econômico-financeiro, pois a Lei exige expressamente a existência de álea extraordinária para que se configure tal situação. Assim, contrato administrativo perfeitamente celebrado, ainda que com falta de expertise da particular, não é passível de revisão judicial. 2) CONTRATO ADMINISTRATIVO. CORREÇÃO MONETÁRIA ANUAL. CLÁUSULA EXPRESSA. INADIMPLÊNCIA POR UM ANO. CORREÇÃO DOS VALORES. O Contrato Administrativo firmado entre a empresa particular e a Administração Municipal de Paranavaí previa expressamente a correção monetária anual pelo IGPM. Igualmente, a Lei $\mathrm{n}^{0}$ 9.069/95 preconiza tal determinação. No entanto, a correção foi feita apenas 24 meses após a assinatura do contrato, fazendo com que a empresa deixasse de receber o valor atualizado por 12 meses - o que, inclusive, gera uma inadimplência por parte da Administração durante todo o período, passível de multa. A perícia judicial demonstrou de modo contundente a existência de tal disparidade. Assim, faz jus o particular ao recebimento das diferenças e multas referentes ao ínterim de seu inadimplemento contratual. 3) APELAÇÃO CÍVEL A QUE SE DÁ PARCIAL PROVIMENTO." (TJPR, Apelação Cível n 907.096-2, Rel. Des. Leonel Cunha, Quinta Câmara Cível, julgado em 06/11/2012) ${ }^{83}$. (grifo meu)

No entanto, no presente caso, verificou-se a total ausência da álea extraordinária, uma vez que não ficou provado qualquer evento fortuito ou abalo econômico que descaracterizaria as condições normais em que foi assinado o contrato administrativo e seus respectivos aditivos ${ }^{84}$. Além disso, o cenário econômico nacional não dá ensejo ao pleito de imprevisibilidade que caracterizaria álea extraordinária. O douto Desembargador ressaltou que e desequilíbrio econômico-financeiro e o inadimplemento são institutos totalmente diversos, visto que o inadimplemento é análise intracontratual e o desequilíbrio, embora afete a obrigação, é extracontratual ${ }^{85}$.

Podemos ainda, analisar o julgado abaixo:

"CONTRATO ADMINISTRATIVO LICITAÇÃO - Obras de recapeamento asfáltico e sinalização horizontal Pretensão da empresa contratada à revisão do contrato administrativo em virtude do aumento dos preços dos produtos asfálticos Alegação da contratada de desequilíbrio econômico-financeiro decorrente do reajuste de preços. DESCABIMENTO - A superveniência de elevação de preços não justifica a revisão do contrato Não demonstrada, no caso concreto, a ocorrência de fatos

\footnotetext{
${ }^{83}$ TJPR, Apelação Cível n. 907.096-2, Rel. Desembargador Leonel Cunha, Paraná, 06 de novembro de 2012 .

84 TJPR, Apelação Cível n. 907.096-2, Rel. Desembargador Leonel Cunha, Paraná, 06 de novembro de 2012.

85 TJPR, Apelação Cível n. 907.096-2, Rel. Desembargador Leonel Cunha, Paraná, 06 de novembro de 2012 .
} 
imprevisíveis, ou previsíveis, porém de consequências incalculáveis, retardadores ou impeditivos da execução do ajustado, consoante exigência contida no art. 65, II, "d" da Lei no 8.666/1993. Manutenção da r. sentença de improcedência. HONORÁRIOS ADVOCATÍCIOS. Majoração, em grau recursal, nos termos do art. 85, §§ $1^{\circ}$ e 11 , do CPC/2015. Observação nesse sentido. RECURSO DE APELAÇÃO DESPROVIDO.” (TJSP, Apelação n ${ }^{0}$ 1004845-57.2016.8.26.0597, Rel. Des. Flora Maria Nesi Tossi Silva, Décima Terceira Câmara de Direito Público, julgado em $25 / 10 / 2017)^{86}$. (grifo meu).

O julgado da Décima Terceira Câmara de Direito Público acima é pertinente para exemplificar que a superveniência da elevação dos preços dos produtos asfálticos não justifica a revisão do contrato administrativo, tendo em vista que é necessária situação de absoluta imprevisão e incalculáveis proporções, inviabilizando a escorreita execução do contrato para ocorrer a revisão e/ou a resolução do contrato administrativo.

A mesma lógica pode ser usada nos Contratos EPC, posto que há fatos extraordinários que não são passíveis de gerenciamento pelas partes contratantes. Tais fatos supervenientes provocam um considerável desequilíbrio econômico-financeiro no EPC pois as partes não possuem os meios necessários para minimizar as consequências desses riscos.

No entanto, o EPC possui hipóteses (pré determinadas pelas partes contratantes) que estabelecem o significado de força maior e determinam as hipóteses que constituem força maior e caso fortuito. Por conseguinte, as hipóteses previamente estabelecidas pelas partes contratantes não são estranhas ao Contrato EPC e não configuram evento de força maior.

\footnotetext{
${ }^{86}$ TJSP, Apelação n. 1004845-57.2016.8.26.0597, Rel. Desembargador Flora Maria Nesi Tossi Silva, São Paulo, 25 de outubro de 2017.
} 


\title{
Capítulo 5: A Alocação Contratual de Riscos
}

Os contratos modernos preocupam-se com a alocação transparente dos riscos que podem ser enfrentados pelas partes ao longo da execução do contrato. A complexidade e o risco contratual são figuras indissociáveis da natureza do modelo EPC. Bons contratos alocam o risco à parte que melhor o gerencia. O FIDIC adota esse princípio e oferece um tratamento abrangente dos riscos.

Para que o risco seja corretamente alocado e mitigado, faz-se necessário identificar quais são eles. Dessa forma, o processo de concorrência que precede a negociação do EPC é de extrema importância, tendo em vista que detalha e especifica todos os possíveis riscos que podem ser incorridos na execução do empreendimento. Com efeito, foi observado que:

\begin{abstract}
"Under the turnkey method of contracting, the tender stage takes on greater importance. Given the short time period available, it may be difficult for the employer to analyse properly each design at tender. Therefore, he will need to be extremely precise in his "request for tender" as to the performance and capacities desired from the works, (known, in the Silver Book, as the Employer's Requirements). The employer will need to spend a greater amount of resources on the tender stage to ensure the contractor and his proposed design are to the requisite quality. Similarly, the contractor may need to expend heavily on bid preparation to ensure the buildability of the project and the profitability of his bid price" ${ }^{87}$.
\end{abstract}

O Red e Yellow Book do FIDIC são conhecidos por administrar o gerenciamento equânime de tais riscos. A alocação contratual de riscos permeia a composição textual dos EPCs: o dono da obra assina um contrato por um preço menor e só tem custos adicionais quando tem que arcar com riscos extraordinários; do outro, o empreiteiro não é obrigado a precificar riscos que dificilmente podem ser quantificados ${ }^{88}$.

\footnotetext{
${ }^{87}$ HUSE, Joseph A. Understanding and Negotiating Turnkey and EPC Contracts. 2 ed. Londres: Sweet \& Maxwell, 2002. p 6-7.

${ }^{88}$ BAPTISTA, Luiz Olavo. Construção Civil e Direito. 2 ed. São Paulo: Lex Editora, 2011. p. 204.
} 
Como explicado acima, a aptidão do mercado de construção foi a evolução de um modelo de contrato que contemplasse a certeza do preço final e entrega do empreendimento, surgindo, assim, o Silver Book: o dono da obra está disposto a pagar consideravelmente mais pelo projeto se eles estiverem certos de que o preço final acordado não será excedido. Assim, o contratado assume responsabilidade por uma gama maior de riscos ${ }^{89}$.

Os pleitos relacionados ao reequilíbrio econômico-financeiro dos contratos EPC sofrem uma distinção, considerando que há pleitos referentes aos riscos contratualmente alocados à Contratante e aos riscos contratualmente alocados à Contratada, que são completamente distintos um do outro.

"A certeza do preço final reclama a assunção de altos riscos pelo contratado. Por outro lado, o dono da obra deve garantir ao contratado o tempo e a oportunidade necessários para que se obtenha toda informação relevante a fim de aferir o preço corretamente. Por vezes, a precificação de riscos por um contratado responsável pode até inviabilizar comercialmente o empreendimento. Quanto maior o risco assumido, maior o preço a ser pago" ${ }^{90}$.

Um dos riscos mais importantes e relevantes na construção de um empreendimento envolvem a alteração nas condições de solo, mais especificamente, os riscos geológicos e geotécnicos na execução do projeto.

A Cláusula 4.10 do FIDIC Silver Book estabelece que o dono da obra deverá disponibilizar ao empreiteiro todos os dados relevantes que tiver em sua posse acerca das condições subterrâneas e hidrológicas do local da obra, incluindo, os aspectos ambientais. No entanto, o empreiteiro tem exclusiva responsabilidade de verificar e interpretar os referidos dados, já que o dono da obra não é responsável pela exatidão, suficiência ou completitude desses dados.

\footnotetext{
${ }^{89}$ BAPTISTA, Luiz Olavo. Construção Civil e Direito. 2 ed. São Paulo: Lex Editora, 2011. p. 204.

${ }^{90}$ BAPTISTA, Luiz Olavo. Construção Civil e Direito. 2 ed. São Paulo: Lex Editora, 2011. p. 204.
} 
Apesar de atribuir substancialmente todos os riscos de construção ao "Epcista", o FIDIC Silver Book estabelece um limite de responsabilidade na Cláusula 17.6.

A limitação de responsabilidade geralmente é um valor equivalente ao preço do EPC, desde que o preço do contrato seja uma boa estimativa do custo de conclusão do empreendimento. No entanto, se o preço for considerado muito baixo, os financiadores do projeto podem exigir um limite maior de responsabilidade.

Há inúmeros outros riscos que são geralmente divididos em nova categorias distintas, quais sejam: (i) riscos de mercado; (ii) riscos financeiros; (iii) riscos tecnológicos; (iv) riscos de construção; (v) riscos operacionais; (vi) riscos regulatórios; (vii) riscos sociais; (viii) riscos de concessão e (ix) riscos de jurisdição. Devido à essa enorme quantidade de riscos, as partes de um contrato precisam identificar tais riscos para que possam ser corretamente alocados e mitigados. Quanto maior o leque de previsões de riscos e métodos mitigadores empregados, menor a hipótese de as obrigações de uma das partes se tornar excessivamente onerosa, pois a incidência do risco, ou as consequências decorrentes de sua ocorrência, estariam devidamente mitigadas.

\subsection{Riscos Contratualmente Alocados à Contratante}

Diversos riscos podem ser contratualmente alocados à Contratante. No entanto, o "Epcista" não irá englobar no preço ofertado à Contratante um valor específico com o intuito de suportar a eventual ocorrência de algum desses riscos. Na hipótese de ocorrer evento que enseje determinado risco, mesmo que previsível e de baixa onerosidade, tal evento pode estar sujeito ao pleito de reequilíbrio econômico-financeiro contratual feito pelo "Epcista" que sofreu as consequências de tal evento. 
O pedido de revisão feito pelo "Epcista" não poderá ser baseado na teoria da imprevisão, visto que o fundamento jurídico do pleito não irá ser a revisão da vontade das partes diante de novas condições fáticas. O pleito de revisão, feito pelo "Epcista", será baseado em situação prevista contratualmente, de que ônus decorrente de um determinado fato deverá ser arcado pela parte a quem o risco foi alocado ${ }^{91}$.

Sendo assim, quando as partes estabelecem no contrato que a Contratante será responsável por um evento que enseje um determinado risco, presume-se que a Contratante irá arcar com os ônus impostos ao projeto em relação à materialização de tal risco ${ }^{92}$.

\begin{abstract}
"Ilustrativamente, se, em um contrato de implantação de planta industrial, as partes atestarem que a eventual ocorrência de descargas atmosféricas acima de um determinado parâmetro não será de responsabilidade do epecista, então, expressa ou implicitamente, declarando sua vontade de que, caso ocorram descargas atmosféricas acima do parâmetro previsto, causando custos que o epecista não havia previsto na formulação de seu preço, em função da mão de obra paralisada, tais custos deverão ser arcados pela contratante. Ou seja, tais custos deverão ser acrescidos ao preço contratual ou pagos diretamente pela contratante. Nesse caso, não será necessário averiguar se a ocorrência do excedente de descargas atmosféricas poderia ter sido previsto, ou se o custo extra da contratada foi ou não excessivamente oneroso. Bastará que o custo não tenha sido previsto na planilha de custos que gerou o preço original e que, razoavelmente, não pudesse ter sido evitado" ${ }^{93}$.
\end{abstract}

Todavia, os riscos contratualmente alocados à Contratante devem respeitar as práticas usualmente adotadas nos contratos EPC. Mudanças das condições técnicas e comerciais inicialmente contratadas e que servem de base para a formulação do preço pelo "Epcista" devem ser necessariamente vistas como riscos que serão contratualmente alocados à Contratante. É importante ressaltar que os contratos EPC baseados no modelo FIDIC dispõem de

\footnotetext{
${ }^{91}$ SILVA, Leonardo Toledo da. Direito e Infraestrutura. Disponível em: < https://books.google.com.br/books?isbn=8502130749>. Acesso em 14 de outubro de 2018.

${ }^{92}$ SILVA, Leonardo Toledo da. Direito e Infraestrutura. Disponível em: < https://books.google.com.br/books?isbn=8502130749>. Acesso em 14 de outubro de 2018 .

${ }^{93}$ SILVA, Leonardo Toledo da. Direito e Infraestrutura. Disponível em: < https://books.google.com.br/books?isbn=8502130749>. Acesso em 14 de outubro de 2018.
} 
cláusula que estabelece que o "Epcista" verificou e aceitou as condições incialmente fornecidas pela Contratante.

Há riscos que são sempre contratualmente alocados à Contratante, como, por exemplo, obter licenças ambientais, liberar o local das obras, a paralisação por decisões de autoridades competentes, etc. Vale lembrar que, no modelo de Contrato EPC há uma grande concentração de riscos ao "Epcista", razão pela qual eventual transferência de grande parte dos riscos à Contratante tende a desconfigurar essa modalidade de contratação ${ }^{94}$.

\subsection{Riscos Contratualmente Alocados à Contratada}

No que tange aos riscos contratualmente alocados à Contratada, ou, "Epcista", é relevante verificar se as partes ao negociarem o Contrato EPC estabelecem mecanismos de soluções aos referidos riscos. O EPC poderá estabelecer que nas hipóteses de atraso das obras, o "Epcista" deverá apresentar um plano de recuperação dos prazos do cronograma físico das obras, independentemente da obrigação ou não das partes de recompor o equilíbrio econômico-financeiro do contrato ${ }^{95}$.

Os requisitos da teoria da imprevisão são verificados como forma supletiva à solução contratual dos riscos. No entanto, como já visto acima, a nossa legislação identifica quatro requisitos que precisam estar presentes na aplicação da teoria da imprevisão que enseje o remédio da revisão ou resolução contratual.

"São os seguintes: 1) contrato de execução periódica, continuada ou diferida; 2) fato imprevisível ou extraordinário superveniente; 3) onerosidade excessiva ou desequilíbrio econômico-contratual; 4) ausência de culpa da parte reclamante. São esses os requisitos que, em nossa compreensão, devem estar sempre presentes para a

\footnotetext{
${ }^{94}$ SILVA, Leonardo Toledo da. Direito e Infraestrutura. Disponível em: < https://books.google.com.br/books?isbn=8502130749>. Acesso em 14 de outubro de 2018.

${ }^{95}$ SILVA, Leonardo Toledo da. Direito e Infraestrutura. Disponível em: < https://books.google.com.br/books?isbn=8502130749>. Acesso em 14 de outubro de 2018.
} 
formulação de um pleito de reequilíbrio econômico-financeiro de um contrato EPC quando não se tratar de risco alocado à Contratante" ${ }^{\text {" }}$.

O primeiro requisito apontado é fácil de se constatar no Contrato EPC pois este é um contrato cujo cumprimento das obrigações contratualmente estipuladas se prolonga no decorrer do tempo.

$\mathrm{O}$ segundo e o terceiro requisitos geram maiores controvérsias como irei analisar adiante. $\mathrm{O}$ "Epcista" elabora o seu preço após analisar todas as condições e premissas inicialmente estipuladas pela Contratante, como visto acima no Capítulo 3. Ou seja, o "Epcista" avalia todos os prováveis riscos que podem acontecer até a conclusão e entrega do projeto.

$O$ pedido de revisão do Contrato EPC referente a um risco contratualmente alocado ao "Epcista", só será justificável quando for possível provar que o fato que ensejou o pleito de reequilíbrio econômico-financeiro é extraordinário e impossível de se prever quando da elaboração do EPC. Poderá ainda demonstrar que, ainda que o fato em si fosse previsível, a proporção e as consequências com que ocorreram não poderiam ser previstas ou quantificadas $^{97}$. O exemplo utilizado é de uma crise econômica que venha assolar o país, será pouco provável que o "Epcista" consiga se prevenir dos efeitos econômicos gerados pela crise caso tais efeitos tenham proporções e consequências inimagináveis. O artigo 65 , II, $d$, da Lei de Licitações demonstra situação de fato imprevisível, ou previsível que gere consequências incalculáveis.

Fatos que pudessem ser previstos pelo "Epcista" na elaboração do contrato não podem ser usados como base para os pedidos de revisão de preço e prazo. Deveria, no caso, o "Epcista" ter incluído no seu preço os custos

\footnotetext{
${ }^{96}$ SILVA, Leonardo Toledo da. Direito e Infraestrutura. Disponível em: < https://books.google.com.br/books?isbn=8502130749>. Acesso em 14 de outubro de 2018.

97 SILVA, Leonardo Toledo da. Direito e Infraestrutura. Disponível em: < https://books.google.com.br/books?isbn=8502130749>. Acesso em 15 de outubro de 2018.
} 
associados ao evento, não podendo a Contratante ser onerada pela falha do "Epcista" ao formular sua proposta ${ }^{98}$.

A apreciação dos pedidos de revisão formulados após a execução do Contrato EPC é subjetiva pois é difícil definir se o "Epcista" deveria ter previsto um determinado fato na elaboração de seu preço. Ou seja, o juízo de imprevisibilidade é altamente subjetivo. Todavia, há determinados eventos que são fáceis de prever e, consequentemente, este juízo é simples. Exemplo disso seria o índice pluviométrico de dezembro a janeiro no Sudeste brasileiro pois todos sabem que esses meses possuem um alto índice pluviométrico. Desta forma, o pleito de reequilíbrio econômico-financeiro fundado com base que os meses de dezembro e janeiro são chuvosos não seria aceitável. Tal pleito só seria aceito caso se provasse que as chuvas ganharam proporções extraordinários quando comparado às proporções médias, e, como consequência, o "Epcista" teria que arcar com os custos que não havia previsto.

"Há, no entanto, situações muito mais complexas e sutis, muitas vezes de caráter eminentemente técnico. Nesses casos, não é a figura do homem médio que deverá ser usada para balizar o juízo de previsibilidade, mas sim a figura do engenheiro experiente. Ou seja, se um engenheiro experiente deveria ter previsto a ocorrência de um determinado evento, então este não deve ser considerado como evento imprevisível"99.

Situação complexa de caráter técnico são os riscos geológicos, considerando que não é possível prever o tamanho das consequências e os problemas decorrentes de tais riscos na execução do empreendimento.

Como dito acima, o terceiro requisito da onerosidade excessiva ou desequilíbrio econômico-financeiro contratual gera controvérsias entre os estudiosos do tema. Para que o "Epcista" consiga fazer seu pedido de revisão

98 SILVA, Leonardo Toledo da. Direito
https://books.google.com.br/books?isbn=8502130749>. Acesso em 15 de outubro de 2018. https://books.google.com.br/books?isbn=8502130749>. Acesso em 15 de outubro de 2018. 
de preço e prazo, não basta que demonstre que determinado evento tenha sido imprevisível the causando custos extras alicerçado na teoria da imprevisão. $\mathrm{O}$ "Epcista" também deverá demonstrar que determinado evento lhe causou onerosidade extremamente excessiva ou que lhe acarretou grave desequilíbrio econômico-contratual no EPC.

É certo que um dos requisitos para aplicar a teoria da imprevisão e gerar a revisão ou resolução do contrato é a necessidade de grave desequilíbrio econômico-contratual. Entretanto, a grande dificuldade desse requisito, gira em torno do fato que não é fácil determinar o que seria 'grave desequilíbrio econômico-contratual', ou seja, tal desequilíbrio não pode estar dentro da álea normal contratual.

Visto não haver fórmulas jurisprudenciais e doutrinárias precisas à interpretação deste grave desequilíbrio ou onerosidade excessiva, cabe ao julgador buscar, no princípio da razoabilidade, a solução da questão ${ }^{100}$.

"Ademais, deve o julgador compreender minimamente como se formou o preço e/ou
prazo contratual posto em xeque ante a situação imprevisível. Primeiramente, a fim
de interpretar o desequilíbrio como um todo, deve, na medida do possível, levar em
consideração todos os custos incorridos pelo epcista até aquele momento para a
execução da obra, e não somente aqueles que variaram em desfavor do epcista. São
comuns pleitos de reequilíbrio econômico que simplesmente apresentam variações
de todos os custos que lhe foram desfavoráveis sem apresentar aqeueles que lhe
foram benéficos. A questão do grave desequilíbrio, em nosso entender, há de ser
vista sob a ótica da execução contratual como um todo, ressalvada eventual avença
das partes em sentido contrário.

Além disso, é necessário que se busquem identificar os valores de contingenciamento no preço formulado pelo epcista. É razoável supor que desequilíbrios inferiores às verbas correspondentes de contingenciamento não sejam interpretados como um grave desequilíbrio" ${ }^{\text {101 }}$.

O quarto requisito, qual seja, a ausência de culpa da parte que pleiteia a revisão do EPC é de fácil constatação. Se a parte reclamante estiver dotada de

100 SILVA, Leonardo Toledo da. Direito e Infraestrutura. Disponível em: < https://books.google.com.br/books?isbn=8502130749>. Acesso em 22 de outubro de 2018.

101 SILVA, Leonardo Toledo da. Direito e Infraestrutura. Disponível em: < https://books.google.com.br/books?isbn=8502130749>. Acesso em 22 de outubro de 2018. 
culpa, deverá arcar com os custos mesmo que tais custos se mostrem excessivamente onerosos.

Há também a possibilidade de contratar seguros para cobrir os riscos. Se o EPC celebrado continha cláusulas de cobertura securitária, não se poderia pleitear a revisão contratual, visto que o dano foi consequência de uma conduta danosa da própria parte.

O quarto requisito pode, inclusive, ser confundido com o requisito da imprevisibilidade. Isso ocorre pois, ao considerarmos que o evento pautado na culpa poderia ter sido evitado através de uma conduta esperada, então, de certo modo, estamos entendendo que se tratava de evento previsível. Tal discussão, todavia, tem consequências quase que meramente terminológicas ${ }^{102}$.

102 SILVA, Leonardo Toledo da. Direito e Infraestrutura. Disponível em: < https://books.google.com.br/books?isbn=8502130749>. Acesso em 23 de outubro de 2018. 


\section{Capítulo 6: Aplicação da Onerosidade Excessiva aos Contratos EPC}

Com o intuito de se aprofundar no tema central da presente monografia, faz-se necessário recordar, em resumidas linhas, algumas ponderações importantes acima desenvolvidas, para simplificar a articulação do instituto da onerosidade excessiva no Contrato EPC.

Até então, foi verificado, que: (i) os contratos EPC se prolongam no tempo, possuem caráter empresarial, sendo a autonomia da vontade um dos principais pilares do direito empresarial em que a qualificação das partes, por si só, exclui a maior parte dos requisitos para a caracterização da "onerosidade excessiva"103; (ii) a complexidade e o risco do EPC estão diretamente relacionados ao conhecimento das partes, o qual forma as premissas da formação do contrato; (iii) tais riscos podem ser melhor desenvolvidos através de investigações específicas dos inúmeros aspectos da obra (riscos hidrometeorológicos, riscos geológicos ou geotécnicos, variações de mercado, alterações legais ou de incidência fiscal, interferências da contratante ou de terceiros, dentre outros); (iv) as partes procuram identificar todos os riscos possíveis na negociação e elaboração do contrato para que estes sejam devidamente alocados e mitigados; (v) presume-se que ao celebrarem o Contrato EPC, as partes estão conscientes dos riscos assumido; e (vi) a alocação contratual de riscos é acompanhada de um sobrecusto para a parte que se exime do risco correspondente.

O artigo 478 do Código Civil estabelece os requisitos para se aplicar o instituto da onerosidade excessiva: (i) contrato de execução diferida; (ii) prestação de uma das partes se tornar excessivamente onerosa com extrema

\footnotetext{
103 COELHO, Fábio Ulhoa. Tratado de Direito Comercial, Volume 5: Obrigações e Contratos Empresariais. São Paulo: Saraiva, 2015.
} 
vantagem para a outra; (iii) em virtude de acontecimentos imprevisíveis e extraordinários.

Destarte, o Contrato EPC se adapta perfeitamente às características detalhadas pelo dispositivo legal acima exposto, dado que, num primeiro olhar, reúne todas os requisitos que se fazem necessários.

No entanto, é necessário ter em mente, que o EPC é um contrato atípico. Os principais aspectos do EPC que se associam ao instituo da onerosidade excessiva são sua existência indissociável e alocação contratual de riscos, incluindo, o regime de preço adotado, tal como, a troca pautada na boa-fé das informações para a realização do empreendimento. Desta forma, o EPC reúne certa álea para acontecimentos supervenientes e imprevisíveis que alterem os fundamentos do negócio.

Presume-se que o "Epcista" ao celebrar o Contrato EPC tenha averiguado todos os dados relevantes disponibilizados pelo dono da obra, e, percebendo, alguma inconstância, tenha advertido o dono da obra para que as informações fornecidas sejam completadas, alteradas, substituídas ou expurgadas. Uma vez aceita a obra, conclui-se que o "Epcista" tenha contemplado com os mínimos detalhes os dados relevantes fornecidos e estejas ciente dos riscos que está assumindo.

Os atos e eventos técnicos incluem também: (i) condições sísmicas ou outras condições ambientais que, considerando as séries históricas de sísmica do local da sede da contratada ou subcontratada (desde que razoavelmente previsíveis); (ii) condições climáticas e pluviométricas que, considerando as séries históricas de meteorologia e hidrologia do local dos últimos cinquenta anos (desde que razoavelmente previsíveis); e (iii) condições pré-existentes no local da obra.

Sendo assim, é possível certificar que fatos supervenientes de ordem técnica não ofereceriam abertura à aplicação à teoria da imprevisão, uma vez que se presume que o "Epcista" tenha efetuado todas as investigações 
indispensáveis e estudos técnicos com o objetivo de conhecer todos os riscos da obra. E, se não previu ou não realizou todo o estudo necessário para tanto, assumiu o risco, como parte de seu negócio, sendo certo que nessa distribuição de responsabilidade e riscos não há de se vislumbrar injustiças.

Assim, dada a autonomia da vontade que prevalece na interpretação do Contrato EPC, por ser celebrado entre empresários/empresas, o afastamento do instituto da onerosidade excessiva é perfeitamente cabível. O "Epcista" tem o dever de mitigar os impactos dos riscos. Quando a mitigação do impacto for fisicamente impossível, poderá tornar-se viável economicamente com a contratação de seguros apropriados.

“As consequências dos erros nas avaliações subjetivas de cada empresário devem ser por ele exclusivamente suportados, não devendo a revisão de contratos ou cláusulas contratuais, ou anulação integral do negócio jurídico, servir para corrigir maus negócios empresariais"

Nesse mesmo sentido, Paula Fargioni também entende os riscos do projeto estão englobados na álea normal do contrato de engenharia e sua ocorrência não seria caracterizado como evento extraordinário.

"Um sistema que permite o contratante liberar-se de seus compromissos porque, no seu entender, a operação não trouxe o lucro pretendido, implicaria a subversão completa da ordem e conduziria a um nível de insegurança e imprevisibilidade comprometedor" 105 .

Todavia, os riscos técnicos não são os únicos assumidos na celebração do Contrato EPC. Outros riscos, como, por exemplo, alterações na legislação e expressiva mudança cambial podem acontecer e esses fatos supervenientes não podem ser gerenciados pelas partes contratantes. Nesses casos, a

${ }^{104}$ WANDERER, Bertrand. A inaplicabilidade, em regra, dos institutos da lesão e onerosidade excessiva aos contratos interempresariais. 2013. 163. Tese (Mestrado). Universidade de Brasília. p. 126.

${ }^{105}$ FORGIONI, Paula A. A interpretação dos negócios empresariais no novo Código Civil brasileiro. Revista de Direito Mercantil, Industrial, Econômico e Financeiro. São Paulo: Malheiros. v. 42, n. 130, abr./jun. 2003. p. 17. 
superveniência irá provocar o desequilíbrio econômico-financeiro substancial no EPC e nenhuma das partes contratantes terá meios para amenizar as repercussões desses riscos. Essas serão as hipóteses sujeitas à aplicação da teoria da imprevisão.

É importante ressaltar que o EPC possui cláusulas que estabelecem os eventos de força maior e caso fortuito que não são estranhos ao contrato. $\mathrm{O}$ próprio contrato estipula que força maior significa qualquer evento cujos efeitos não eram possíveis evitar ou impedir e que impeçam qualquer das partes de cumprir as obrigações pactuadas, incluindo: (i) quaisquer atos de natureza, tais como, incêndios, inundações, terremotos, naufrágios, tufões e furações, ou quaisquer outras condições climáticas anormais que sejam imprevisíveis; e (ii) quaisquer eventos inesperados causados pelo homem, que estejam fora do controle das partes e que afetem a execução do contrato, tais como, perturbação da ordem pública, epidemia, guerras, boicotes, sabotagem, atos terroristas, bloqueios, greves gerais e interrupções de trabalho não justificadas provocadas por fatores alheios à vontade e interferência das partes.

Quando ocorrem tais eventos, o EPC já estipula a redução dos impactos e meios justos para conceber a revisão do preço contratual e a concessão de extensão de prazo para a conclusão das obras, tendo em vista o reequilíbrio econômico-financeiro contratual sem a necessidade de se levar tal contrato a juízo ou arbitragem. 


\section{Conclusão}

Em vista dos poucos estudos disponíveis, há uma enorme dificuldade entre os intérpretes brasileiros na qualificação do Contrato EPC, que é complexo por natureza e possui a elasticidade para abrigar em seu seio a multiplicidade de atividades instrumentais, interdependentes e indivisíveis com o fim único de executar certo projeto.

No entanto, é evidente que a teoria da imprevisão pode ser imposta ao Contrato EPC quando presente determinados requisitos. Na elaboração e negociação dos Contratos EPC, as partes contratantes se preocupam na identificação e na eficiente alocação dos riscos contratuais que podem vir a surgir na execução do EPC visto que o EPC é um contrato de execução diferida no tempo. No entanto, não há verificação da imprevisibilidade quando o risco incorrido pelas partes compõe a álea ordinária do negócio contratual.

O princípio da autonomia da vontade norteia a elaboração dos contratos empresariais, e, consequentemente, é um princípio predominante na elaboração, negociação e execução dos Contratos EPC. Todavia, a assunção de riscos contratuais não pode e nem deve caracterizar injustiças, visto que as partes contratantes estão em pés de igualdade e paridade material. Ou seja, as partes contratantes conhecem os riscos que estão sendo assumidos visto que que possuem conhecimento técnico e expertise em suas áreas. Desta forma, a efetiva alocação contratual de riscos envolve um sobrecusto para a parte que deles se exime, mas, representa a melhor forma para impedir a ocorrência da teoria da imprevisão.

É importante destacar que a onerosidade excessiva trata de riscos imprevisíveis, ou seja, os riscos que estão fora do alcance da capacidade cognitiva dos homens.

Destarte, para que a eficiente alocação de riscos contratuais ocorra, as partes precisam identificar todos os riscos para que eles possam ser mitigados. 
Resta evidente, ainda, que riscos somente são incontroláveis quando as partes contratantes não sabem quais são os meios necessários geralmente postos em prática para se prevenir de tais riscos. Constatação essa que se reduz proporcionalmente à elaboração dos projetos da obra, o fornecimento dos equipamentos, tecnologia e treinamento para operar os empreendimentos, o conhecimento técnico exigido pelo dono da obra das condições geológicas e climáticas, bem como a feição empresarial encerrando o ajuste um instrumento produtivo e o elemento aleatório decorrente dos riscos assumidos.

Uma vez que uma das partes contrai riscos adicionais, se presume que tenha assumido os referidos riscos de forma consciente. Pois

"Em sede de contratos empresariais, os contratantes assumem o risco dos acontecimentos pela falta de diligência no momento da sua celebração" ${ }^{06}$.

A parte que arca com o sobrecusto transfere para a outra o risco de arcar com as consequências de um evento danoso. No entanto, a contratação de fianças bancárias que asseguram, a contratação de seguros garantia que asseguram a conclusão das obras objeto do contrato e a contratação de seguros para se prevenir dos danos que podem se suceder são sempre realizadas no âmbito do Contrato EPC.

Contudo, resta claro, que sempre haverá acontecimentos desconhecidos e impossíveis de serem previstos, principalmente alterações legislativas e políticas. As hipóteses em que, eventos desconhecidos e imprevisíveis causam um desequilíbrio econômico substancial na relação entre as partes contratantes e tais partes não conseguem atenuar os impactos pois não possuem os meios necessários, são mais suscetíveis à aplicação da teoria da imprevisão.

\footnotetext{
106 WANDERER, Bertrand. A inaplicabilidade, em regra, dos institutos da lesão e onerosidade excessiva aos contratos interempresariais. 2013. 163. Tese (Mestrado). Universidade de Brasília. p. 134.
} 
Também é importante ressaltar que os meios usados para reajustar os valores inicialmente pactuados no EPC quando há é possível verificar a ocorrência das hipóteses de caso fortuito e força maior, bem como ordens de reajuste, demonstram a boa-fé das partes contratantes pois as tais ordens de alteração feitas pelo dono da obra permitem a conservação e continuidade do EPC.

Assim, quanto maior a quantidade de riscos previstos e eficientemente alocados no Contrato EPC, menor a possibilidade de pleitos relativos à revisão ou resolução do contrato com fulcro nos artigos 478 a 480 do Código Civil. É preferível a revisão das cláusulas contratuais ao invés da resolução do contrato, dada a função social do contrato, sendo certo que a continuação de uma obra de grande porte de engenharia, geralmente de infraestrutura, é de inegável interesse coletivo, devido à geração de emprego, riqueza e sua utilidade coletiva. 


\section{Bibliografia}

AMARAL, Antônio Carlos Cintra do. Anulação de contrato já cumprido. Alteração do método construtivo e alteração do objeto contratual. Faturamento direto à contratante, efetuado por subcontratada. Revista Brasileira de Infraestrutura - RBINF. Belo Horizonte: Editora Fórum, 2012.

BAPTISTA, Luiz Olavo. Construção Civil e Direito. 2 ed. São Paulo: Lex Editora, 2011.p. 204.

CHEN, Daniel Shem Cheng. Contrato de Engineering. Disponível em: $<\mathrm{http}: / /$ www.ambitojuridico.com.br/site/?n_link=revista_artigos_leitura\&artigo_id $=12257>$. Acesso em 04 de novembro de 2018.

COASE, Ronald. Why Economics Will Change. Comentários proferidos na Universidade de Missouri, Columbia, Missouri, em 4 de abril de 2002. Disponível em: $<$ http://coase.org/coaseremarks2002.htm>. Acesso em 04 de novembro de 2018.

COELHO, Fábio Ulhoa. Tratado de Direito Comercial, Volume 5: Obrigações e Contratos Empresariais. São Paulo: Saraiva, 2015. p.

FIDIC Condições Contratuais para Projetos Chave na Mão. Condições gerais, guia para a preparação das condições particulares, minutas da carta-proposta, acordo contratual e acordo de resolução de conflitos. Genebra, FIDIC, 1. ed.. 1999. 
FORGIONI, Paula A. A interpretação dos negócios empresariais no novo Código Civil brasileiro. Revista de Direito Mercantil, Industrial, Econômico e Financeiro. São Paulo: Malheiros. v. 42, n. 130, abr.jun. 2003. p. 17.

FOUNTOURA, Rodrigo Brandão. Onerosidade Excessiva nos Contratos de Comercialização de Energia Elétrica. VIVAN, Alexei Macorin; SILVEIRA, Rodrigo Maito da. Direito e energia. São Paulo: Quartier Latin, 2014. p. 179.

GIL, Fabio Coutinho de Alcântara. A Onerosidade Excessiva em Contratos de Engineering. São Paulo, 2007. 146. Tese (Doutorado). Universidade de São Paulo. p. 13.

GRIZENDI, Eduardo; GRILO, Leonardo M.; PAIVA, Ricardo N.; ALVES, Rubens; e RUSSO, Waldo A. PPP - Parcerias Público-Privadas Experiência Internacional no Setor Aeroespacial. Rio de Janeiro: E-papers Serviços Editoriais Ltda., 2011. p. 27.

GOZZI, Elcio Fagundes Marques. Contrato EPC (Engineering, Procurement e Construction) e o Padrão FIDIC. São Paulo. 2016. 94. Tese (Mestrado). Escola de Direito de São Paulo da Fundação Getúlio Vargas. p. 18.

HUSE, Joseph A. Understanding and Negotiating Turnkey and EPC Contracts. 2 ed. Londres: Sweet \& Maxwell, 2002. p 6-7.

MARCONDES, Fernando. Temas de Direito da Construção: Contratos de Construção por Administração com Preço Máximo Garantido: a Lógica Econômica e a Apuração dos Resultados. $1^{\text {a }}$ ed.. São Paulo: Pini, 2015. p. 11. 
MARIANGELO, Rafael. Temas de Direito da Construção: Aspectos Relevantes dos Modelos Contratuais FIDIC. 1 ${ }^{\mathrm{a}}$ ed.. São Paulo: Pini, 2015. p. 207.

MESQUITA, Marcelo Alencar Botelho. Contratos Chave Na Mão (Turnkey) e EPC: Conteúdo e Qualificações. Florianópolis. 2017. 212. Tese (Mestrado). Universidade Federal de Santa Catarina. p. 15.

PEREIRA, Caio Mário da Silva de. Instituições de Direito Civil, volume III: Contratos. 13 ed. Rio de Janeiro: Forense, 2009. p. 166.

PINTO, José Emílio Nunes. O contrato EPC para construção de grandes obras de engenharia e o novo Código Civil. Disponível em $<$ http://jus.com.br/artigos/2806/o-contrato-de-epc-para-construcao-de-grandesobras-de-engenharia-e-o-novo-codigo-civil $>$. Acesso em 04 de novembro de 2018.

SILVA, Leonardo Toledo da. Direito e Infraestrutura. Disponível em: < https://books.google.com.br/books?isbn=8502130749>. Acesso em 04 de novembro de 2018.

VENOSA, Sílvio de Salvo. Direito Civil: Teoria Geral das Obrigações e Teoria Geral dos Contratos. 14ª ed.. São Paulo: Atlas, 2014.

WANDERER, Bertrand. A inaplicabilidade, em regra, dos institutos da lesão e onerosidade excessiva aos contratos interempresariais. 2013. 163. Tese (Mestrado). Universidade de Brasília. 